\title{
A revision of the genus Dalatagonum (Coleoptera: Carabidae: Platynini)
}

\section{Ревизия рода Dalatagonum (Coleoptera: Carabidae: Platynini)}

\author{
D.N. Fedorenko \\ A.H. Федоренко
}

\begin{abstract}
A.N. Severtsov Institute of ecology and evolution, Leninsky pr. 33, Moscow 119071 Russia.
Институт проблем экологии и эволюции им. А.Н. Северцова, Российская Академия Наук, Ленинский пр-т, Москва 119071 Россия. E-mail: dmitri-fedorenko@yandex.ru
\end{abstract}

KEY WORDS: Coleoptera, Carabidae, Dalatagonum, new species, Vietnam.

КЛЮЧЕВЫЕ СЛОВА: Coleoptera, Carabidae, Pterostichus, Dalatagonum, новый вид, Вьетнам.

ABSTRACT. The genus Dalatagonum Fedorenko, 2011 is revised. Six new species, D. amariforme, $D$. convexicolle, D. laticolle, D. quadrisetosum, D. rotundatum, and D. rufipes spp.n., all from Vietnam are described. Two new species groups are established. Key to species is provided.

РЕЗЮМЕ. Ревизован род Dalatagonum Fedorenko, 2011. Описаны 6 новых видов из Вьетнама: $D$. amariforme, D. convexicolle, D. laticolle, D. quadrisetosum, D. rotundatum, and D. rufipes spp.n. Установлены 2 новые видовые группы. Составлена таблица для определения видов рода.

\section{Introduction}

The genus Dalatagonum Fedorenko, 2011 belongs to the carabid tribe Platynini. It includes nine species from Vietnam, eight from the Dalat Plateau in southern Vietnam and one from the Ngoc Linh Mts in central Vietnam. These apterous small-sized beetles occur on the underside of various tree-limbs on the ground in monsoon broad-leaved or mixed forests at 1,400-1,900 $\mathrm{m}$ altitudes. In the Dalat Plateau, most if not all of the species are known to be sympatric and co-occurring.

Based on fresh material from Vietnam, we describe new six species to the genus and re-arrange species into species groups. The material was collected during several collecting trips to Vietnam, sponsored by the Russia-Vietnam Tropical Centre.

The acronyms used are: SIEE — the author's reference collection at A.N. Severtsov Institute of Ecology \& Evolution, Russian Academy of Sciences, Moscow; ZISP - Zoological Institute, Russian Academy of Sciences, St. Petersburg; ZMMU - Zoological Museum of the Moscow State University.

The following morphometric parameters were used: AnL - lengths of antennomeres 1 to $4(n=1,2,3,4)$, used in antennal ratio $\mathrm{AR}=\mathrm{A} 1 \mathrm{~L} / \mathrm{A} 3 \mathrm{~L}: \mathrm{A} 2 \mathrm{~L} / \mathrm{A} 3 \mathrm{~L}: \mathrm{A} 4 \mathrm{~L} /$ A3L; BL - maximum body length, measured between apices of closed mandibles and apices of elytra; EL length of elytron, measured from the apicalmost point of the basal ridge to apex; EW - maximum width of elytra; Es3L - length of metepisternum along basal margin; Es3W - width of metepisternum along outer margin; HW - width of head across eyes; MT1L length of metatarsomere 1 ; MT2-4L - length of metatarsomeres 2 to 4 combined, excluding apical lobes of MT4; MxP3L - length of maxillary palpomere 3; MxP4L — length of maxillary palpomere 4; PA width of pronotum between apical angles; PB - width of pronotal base; $\mathrm{PBl}$ - width of lateral lobes of pronotal base; $\mathrm{PBm}$ - width of median part of pronotal base; PL - length of pronotum along median line; PLw - distance between base and level of maximum width of pronotum; PW - maximum width of pronotum. SSc - parascutellar seta ratio $(s / \mathbf{n}: s-a[a-s] / \mathbf{n}: a)$ n) is used for the following patterns observed in $\mathbf{n}$ specimens examined $(\mathrm{n}=s+s-a[a-s]+a): s$ - parascutellar seta $(S S c)$ separated from stria 2 on both elytra; $a-S S c$ adjoining either stria 2 or short common base of striae 1 and 2 on both elytra.

Measurements were taken using an eyepiece micrometer, to two decimal places. The number of specimens measured (n) is only given for the first ratio in the description; means are in round brackets. Data on labels of type specimens are in quotes.

\section{Systematic part}

Genus Dalatagonum Fedorenko, 2011

Type species: Dalatagonum calathoides Fedorenko, 2011.

REDESCRIPTION. Body (Figs 1-7) rather small, BL 4.3-10 mm, glabrous, mostly Amara- or Calathus-like. Dorsum shiny, black or piceous black; often pronotum along sides and elytral suture being slightly to much paler. Anten-

How to cite this article: Fedorenko D.N. 2018. A revision of the genus Dalatagonum (Coleoptera: Carabidae: Platynini) // Russian Entomol. J. Vol.27. No.4. P.347-362. doi: 10.15298/rusentj.27.4.01 
nae, mouthparts and often also labrum reddish-yellow, legs reddish yellow to reddish brown, often femora and sometimes also tibiae infuscated.

Microsculpture distinct isodiametric on head, superficial on elytra and at middle of pronotal disc, consisting of transverse meshes that become increasingly oblique towards pronotal lateral margin.

Head small relative to pronotum, without neck constriction, bisetose above each eye; posterior supraocular seta approximately on a level with posterior margin of eye; clypeus bisetose. Eyes rather small, slightly flattened to very flat, extended into genae in a straight line; gena ca. $0.3-1$ times as long as eye, extended into neck in a smooth arc. Frontal foveae very short, indistinct or almost so. Antennae pubescent from segment 4 onward, long, mostly surpassing pronotal base by apical 2-3 segments; scape with seta, pedicel with short ventro-apical seta, antennomere 3 with no setae other than verticellate ones. AR $0.84-1.49: 0.44-0.76: 1.06-1.48$; out of basal four antennomeres, 4 th longest, rarely as long as or barely shorter than scape.

Labrum sexsetose, nearly square, truncate to barely sinuate apically. Mandibles slender, long, nearly straight, with apices slightly incurved; dorsal scrobal ridge sinuate, ventral one exposed, broadened, explanate, very thin. Maxillary palps long, terminal palpomere longer to shorter than penultimate one; stipes with two lateral setae, basal and apical.
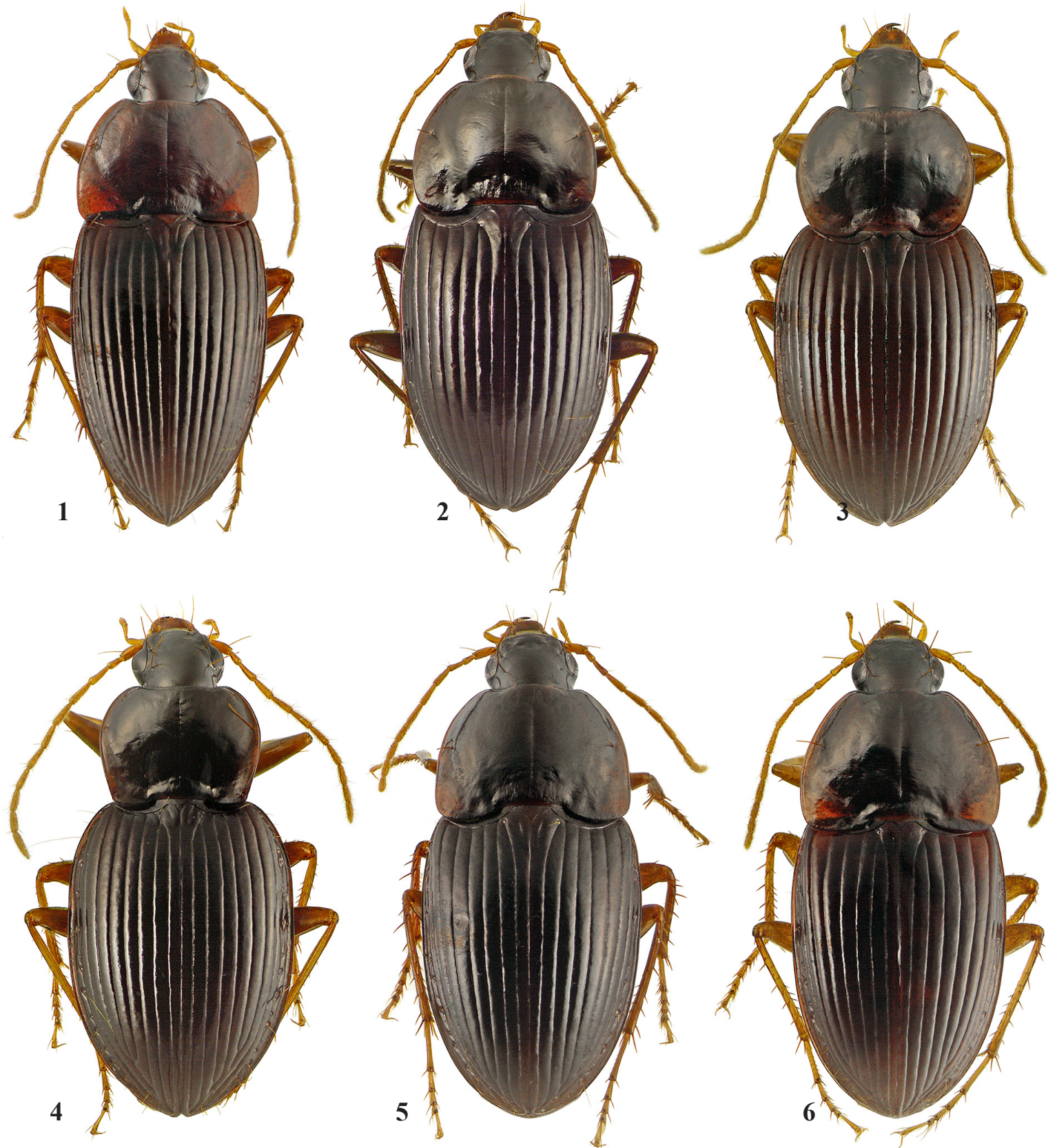

Figs 1-6. Dalatagonum spp., dorsal habitus: $1-$ D. amariforme sp.n.; $2-D$. convexicolle sp.n.; $3-D$. rotundatum sp.n.; $4-D$. quadrisetosum sp.n.; 5 - D. rufipes sp.n.; $6-$ D. laticolle sp.n.; 1, 6- holotypes; 2-5 - paratypes.

Рис. 1-6. Dalatagonum spp., дорсально: 1 - D. amariforme sp.n.; 2 - D. convexicolle sp.n.; 3 - D. rotundatum sp.n.; 4 - D. quadrisetosum sp.n.; 5 - D. rufipes sp.n.; 6 - D. laticolle sp.n.; 1, 6 - голотипы; 2-5 - паратипы. 
Mentum with lateral lobes pointed and separated by deep impressed lines from very narrow epilobes; these lines converging basad and terminating in fairly deep pits; mentum tooth pointed, beaded, slightly shorter than the lobes, with two close setae at base. Submentum bisetose.

Pronotum mostly trapezoidal, much broader basally than apically, broadest just before or closer to base, with sides rounded, more so posteriorly, basal angles rounded to rounded off. Lateral margin increasingly explanate basad, wide or very wide yet mostly not or slightly reflexed basally. Base with very wide lateral lobes produced beyond truncate median part and rounded posteriorly. Each side mostly with single, anterolateral, seta at a distance from lateral edge, rarely with two setae or none. Basal bead missing, apical bead fine or very so; lateral bead fine, obliterate at or distinctly before basal angle. Median line shallow to moderately deep, obsolete anteriorly and often also posteriorly. Basal foveae and both transverse impressions, basal and apical, very shallow to indistinct. Surface even and smooth, often finely strigose just before base and sometimes also behind apex.

Mesothoracic scutellum very large, wide, slightly obtuse. Elytra connate, rather convex, without preapical sinuation; extreme apices slightly separate, sometimes contiguous and rounded or truncate combined; lateral edge extended into apical bead which is separated from interval 3. Base wide, subtruncate; humeri angulate, slightly above to slightly below the meeting point of base and mesothoracic peduncle (Figs 8-9), mostly concealed with lateral pronotal lobes, not or almost indistinctly toothed. Basal ridge convex apicad, humeral angle slightly acute to (rarely) obtuse. Striae deep impunctate; intervals flat to convex, more convex and narrower laterally and apically. Stria 1 anteriorly reaching either parascutellar setigerous pore $(S S c)$ or basal ridge; stria 7 anteriorly either reaching basal ridge (the blattoides-group) or almost reaching humerus (the calathoides-group and the anichkini-group), or joining lateral groove behind humerus (the bidoupense-group); with two preapical setae. Parascutellar striole entire and deep to obsolete. Apical presutural seta and discal setae missing. Interval 9 with umbilical seta series continuous, consisting of 15-16 setigerous pores (US); these adjoining stria 8, with US2-3 additionally adjoining lateral groove while US1 adjoining lateral groove only; the bidoupense-group is defined by US1-2 adjoining lateral groove, with US2 additionally adjoining stria 7.

Underside smooth. Prosternal process not beaded, with subcarinate apical declivity. Metepisternum shorter than wide because of apterous condition, Es3W/Es3L 1.17-2.0. Abdominal sternites IV-VI with one pair of ambulatory setae; sternite VII bisetose $\left(O^{7}\right)$ or quadrisetose $(+)$.

Legs long to (rarely) short. Pro-, meso- and metacoxa ( $c x 1, c x 2$, and $c x 3$, respectively): $c x 1$ asetose, $c x 2$ with two setae, inner and outer; $c x 3$ bisetose (inner seta missing). Trochanters ( $t r)$ : $t r 1$ with seta; $t r 2$ with vestigial, nearly indistinct, or (rarely) short seta; $\operatorname{tr} 3$ with vestigial or no seta. Femora $(f e)$ ventrally flattened or shallowly grooved in apical half $(f e l)$ to nearly throughout except basally, these flats or grooves being edged or finely carinate on each side; $f e l$ with two posterior setae, basal and medioventral; $f e 3$ with median anteroventral seta well-developed (D. broteroides) to short (D. calathoides) or missing (the other congeners). Tibiae ( $t i)$ : til anteriorly with a conspicuous longitudinal sulcus bearing mostly one, vestigial, preapical seta; $t i 2$ and $t i 3$ cruciform in cross-section due to blunt inner and outer ridges separated from sharp lateral ridges by more or less deep grooves; $t i 2$

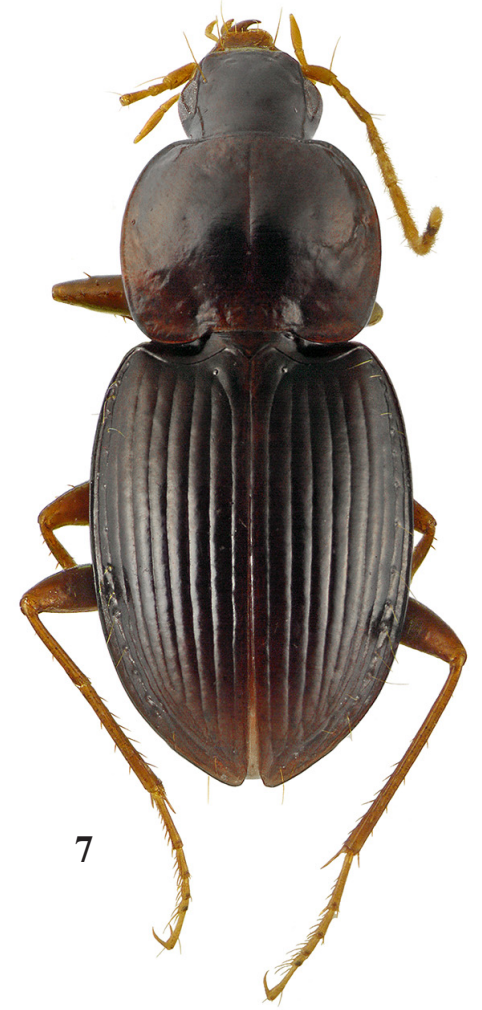

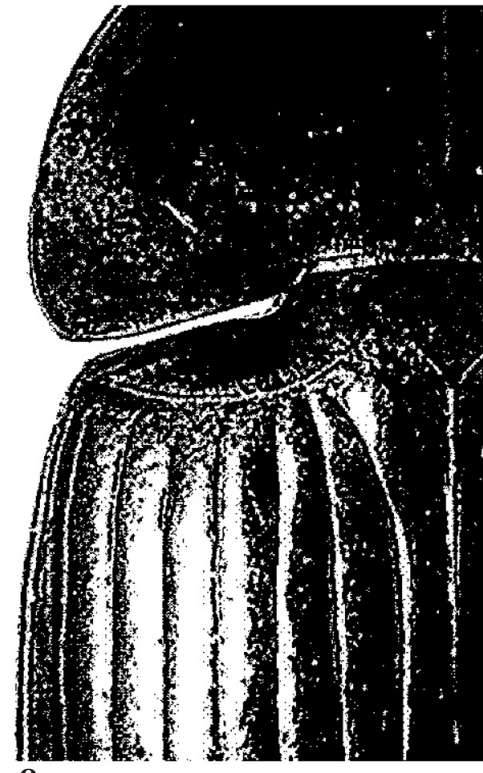

8

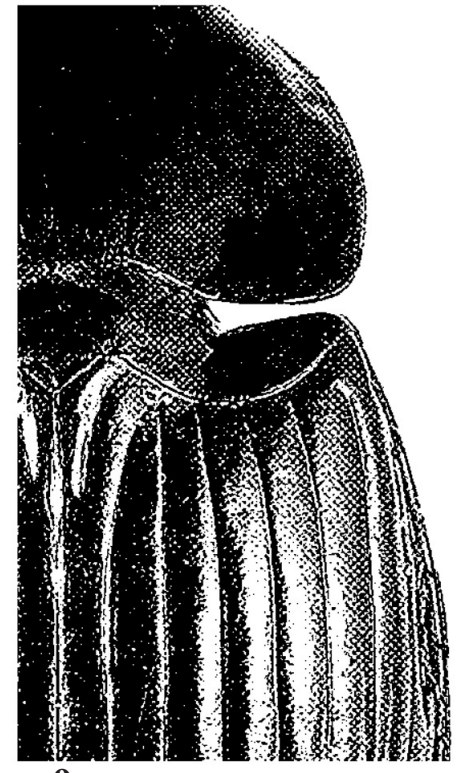

9

Figs 7-9. Dalatagonum: 7 - D. anichkini, holotype, dorsal habitus; $8-$ D. ellipticum; $9-$ D. calathoides; 8-9 bases of pronotum and elytra.

Рис. 7-9. Dalatagonum: 7 - D. anichkini, голотип, дорсально; 8-D. ellipticum; 9 - D. calathoides; 8-9 основания переднеспинки и надкрылий. 
with 1-2 spiniform setae at outer ridge, either preapical (most species) or preapical plus postmedian (the anichkini-group; the calathoides-group, excluding D. elongatus); ti3 externally glabrous; $t i 2$ and $t i 3$ with 5-6 long spiniform setae running along and just outside anterolateral ridge, 5-6 shorter ones along posterolateral ridge, and similar apical setae; apical movable spurs long, slightly more than half as long as tarsomere 1. Tarsi (ta) with tarsomeres 1-2 (tal) or 1-3 (ta2 and ta3) bisulcate, outer sulcus being conspicuous, inner one shallow or very so, weaker in ta3; metatarsomere 4 apically truncate, indistinctly emarginate in ventral view, with extremely short to inconspicuous posterior (inner) lobe; mesoand metatarsomere 4 slightly to moderately bilobed, with anterior (outer) lobe being slightly to almost indistinctly longer and wider than inner lobe; $t a 2$ and especially ta 3 long, MT1L/MT2-4L 0.80-1.29; tarsomeres 1-4 with latero-apical setae, tarsomeres 1-2 with dorso-apical setae; pro- and mesotarsomere 4 with inner ventro-apical setae membranous scale-like; tarsomere 5 glabrous ventrally, claws simple. Protarsomeres 1-3 dilated and biserially squamose ventrally in male, sometimes (D. rufipes sp.n., D. rotundatum sp.n.) barely dilated, with ventral pad absent from tarsomere 3 .

Male genitalia. Tergite IX (T9), or ring sclerite, triangular to quadrangular, with base narrow to wide (Figs 10-22). Aedeagus median lobe (Figs 23-48) slightly asymmetrical, widely membranous except at base, with a fairly narrow sclerotized bottom; apex mostly long and tapered. Internal sac without larger spines, except in two species. Parameres equally long.

Female gonosubcoxite IX with a row of sparse setae along apical margin, gonocoxite IX with one dorsal and 2-3 outer (ventral) ensiform setae. Female reproductive tract: bursa copulatrix membranous; when empty, invaginate basally; spermatheca fusiform annulated.

DIAGNOSIS. The genus includes fairly small-sized apterous Platynini with short metepisterna. Most species are easily recognizable by having (ob)trapezoidal pronotum with no posterolateral seta, large basolateral pronotal lobes, and connate elytra lacking discal setae. Further distinctive features are $t i 2$ and $t i 3$ strongly armed with sparse spiniform setae, rather flat eyes, and long and slender mandibles.

DISTRIBUTION. Eight species of the genus have hitherto been recorded in the Dalat Plateau within the Lam Dong and Khanh Hoa provinces, and one in the northern Tay Nguen Plateau (=Central Highlands), Vietnam. Three species described below populate the Dak Lak Plateau as the northern part of the Dalat Plateau, two are confined to the northern Tay Nguen Plateau, and one species extends the genus range northwards as far as northern Vietnam.

HABITATS AND HABITS. All members of the genus are mid-montane forest-dwellers. Adults occur chiefly on the underside of tree-limbs or tree trunks on the ground in monsoon broad-leaved or mixed forests at 1,000-1,900 (mostly $1,300-1,800) \mathrm{m}$ elevations.

COMMENTS. The species of the genus were arranged into two species groups, the blattoides-group and the calathoidesgroup, in accordance with particular elytral striation [Fedorenko, 2011]. Two of totally six species described below are distinctive among the congeners in having quadrisetose pronotum and further two in the protarsi barely dilated in male, with basal two (vs three) protarsomeres being biserially squamose. These unknown characters invited a revision the genus. As a result, the calathoides-group is here divided into three groups, including the anichkini-group nov. and the bidoupense-group nov. The species with quadrisetose pronotum are shared among the blattoides-group and the anichkini-group, and the species with distinctive male tarsi among the anichkini-group and the $b i$ - doupense-group. - The basal two protarsomeres biserially squamose in male and posterolateral pronotal seta missing are here considered as parallel developments in the genus.

The calathoides-group and the anichkini-group share very similar elytral striation (symplesiomorphy). Externally bisetose $t i 2$ is another symplesiomorphy (except in $D$. elongatus). Further plesiomorphies include $f e 3$ (D. calathoides, $D$. broteroides) and $\operatorname{tr} 3(D$. broteroides) with fixed seta. The following three plesiomorphies, (1) small quadrisetose pronotum with (2) fairly small basolateral lobes and (3) rather short and not very slender mandibles, combined with the northernmost distribution, may suggest the basalmost position of D. quadrisetosum sp.n. in the group(s) and the northern origin of the genus.

Elytral striation of the bidoupense-group and that of the blattoides-group are probably derived character. Barely dilated male protarsi observed in some species of the $b i$ doupense-group (P. rufipes sp.n.) and the anichkini-group $(P$. rotundatum sp.n.) may be underlying synapomorphies, which suggests closer relationships between the bidoupensegroup and the anichkini-group ( + the calathoides-group). The blattoides-group is exclusively defined by synapomorphies, but for a quadrisetose pronotum of $D$. amariforme. Suggested relationships within Dalatagonum are as follows: the blattoides-group $+(($ the anichkini-group + the calathoidesgroup) + the bidoupense-group).

Key to SPECIES AND SPECIES GROUPS OF DALATAGONUM.

1. Elytra with stria 7 basally joining basal ridge; base slightly oblique to humerus (Fig. 8). Body robust, Amara-like, with subequally very wide pronotal and elytral bases. Pronotum with 0-2 setae on each side. Mesotibia externally with one seta, preapical. Body piceous to black, with contrastingly pale appendages; pronotal lateral margin very widely explanate behind the middle, pale or distinctly translucent with red. - The blattoides-group........ 2

- Elytra with stria 7 almost reaching humerus; base truncate or oblique from humerus to mesothoracic peduncle (Fig. 9). Body slender, pronotum and elytra narrower at bases. Dorsum dark brown to black, femora mostly infuscated, pronotal lateral margin slightly to indistinctly translucent with red or brown. Pronotum with 1-2 setae on each side; base with median part wide, mostly much more than a third broader than lateral lobes. Mesotibia externally with 1-2 setae Pronotum bisetose (posterolateral seta missing), with base about as wide as basolateral lobes. Mesotibia externally with preapical seta. Metafemur glabrous. Body small, BL 4.9-6.1 mm. 10

2. Pronotum bisetose on each side, with basolateral lobes truncate posteriorly. BL 5.7-6.3 $\mathrm{mm}$; pronotum dark reddish brown, lateral margin translucent with red. ...... 4. D. amariforme sp.n.

- Pronotum with one, anterolateral, seta on each side.... 3.

- Pronotum asetose. Body sericeous black, pronotum posterolaterally translucent with deep red, femora and coxae slightly infuscated. BL $5.6 \mathrm{~mm}$. ............ 3. D. sericeum

3. Body large, BL $6.4-7.7 \mathrm{~mm}$. Legs long, $t i 2$ and $t i 3$ with very long spiniform setae. Pronotal basolateral lobes distinctly rounded posteriorly. Body piceous black, elytral suture and sides more narrowly and less distinctly pale. 1. D. blattoides

- Body small, BL 4.3-4.9 mm. Legs short, $t i 2$ and $t i 3$ with shorter spiniform setae. Pronotal basolateral lobes very gently rounded posteriorly. Elytral suture and sides more 
widely and more distinctly pale, more so apically......... 2. D. ellipticum

4. Body large, BL $6.7-10 \mathrm{~mm}$. Pronotal base with median part distinctly to much broader than lateral lobes, $\mathrm{PBm} / \mathrm{PBl} 1.5$ 3.7; terminal maxillary palpomere shorter than penultimate one, MxP4L/MxP3L 0.77-0.92. Pronotum with anterolateral seta. - The calathoides-group.

- Body small, BL 5.4-6.3 mm. Pronotal base with median part slightly to distinctly broader than lateral lobes, $\mathrm{PBm} /$ PBl 1.26-1.63; terminal maxillary palpomere longer than penultimate one, MxP4L/MxP3L 1.17-1.47. Pronotum with 1-2 setae on each side. Mesotibia externally bisetose. Metafemur glabrous. - The anichkini-group...... 8

5. Body slender, Europhilus-like, BL $8.6 \mathrm{~mm}$. Pronotum very narrow, barely wider than long, broadest just before middle; base with median part very much broader than almost indistinct lateral lobes; explanate lateral margin narrow yet strongly reflexed. Eyes small and flat, about as long as genae. Metafemur with median seta.

8. D. broteroides

- Body more robust, Calathus-like, PW/PL 1.3-1.6, pronotum broadest 1/4-2/5 from base; base with median part 1.46-2.2 times as wide as lateral lobes; explanate lateral margin barely to moderately reflexed. Eyes larger, distinctly longer than genae.

6. Body large $\mathrm{BL}$ 9-10 mm. Mesotibia externally with preapical seta. Pronotum with explanate lateral margin abruptly and rather strongly reflexed all along. Elytral interval 7 costate basally. Metafemur without anteroventral seta. .............................................. 5. D. elongatum

- Body smaller, BL under $8.7 \mathrm{~mm}$. Mesotibia externally bisetose. Pronotum with explanate lateral margin slightly reflexed. Elytral interval 7 subcostate basally. ........... 7

7. Pronotal setigerous pore 1.5-2 pore diameters distant from lateral edge. Metafemur with medial anteroventral seta. Pronotum narrower, about a third wider than long, with median part of base twice as wide as basolateral lobes. BL 6.7-8.1 mm. ................... 6. D. calathoides

- Pronotal setigerous pore 3.5-5 pore diameters distant from lateral edge. Metafemur glabrous. Pronotum broad, three fifths wider than long, with median part of base only half longer than basolateral lobes. BL $6.9-8.3 \mathrm{~mm}$.......

$$
\text { 7. D. convexicolle sp.n. }
$$

8. Pronotum bisetose on each side, broadest before middle, small, EW/PW 1.36. Elytral microsculpture consisting of very dense transverse lines not forming meshes. 11. D. quadrisetosum sp.n.

- Pronotum with anterolateral seta, broadest just behind middle; elytra a fourth wider than pronotum. Elytral microsculpture consisting of very transverse meshes, with admixture of dense transverse lines.

9. Pronotum less rounded on sides, longer and narrower, less than a third wider than long, four fifths wider than head; apex nearly truncate, with hardly projecting angles; microsculpture traceable before middle, obliterate behind. Body black, femora infuscated. Protarsomeres 1-3 dilated and with ventral pad in male. .......... 9. D. anichkini

- Pronotum strongly rounded on sides, shorter and wider, two fifths wider than long and almost twice as wide as head; apical angles distinctly projecting; microsculpture superficial yet traceable over disc. Body piceous black, legs red, with barely infuscated femora. Protarsomeres 13 barely dilated, with ventral pad absent from tarsomere 3 , in male. 10. D. rotundatum sp.n.

10. Pronotum trapezoidal, broadest about a fourth from base, with base almost twice as wide as apex. Legs red. ... 11
- Pronotum obtrapezoidal, broadest two fifths from base, with base narrower and sides more rounded in basal half. Femora infuscated. Protarsomeres 1-3 dilated and biserially squamose on ventral side in male. .................... 12

11. Pronotum nearly parallel-sided in basal half, with rather narrowly rounded basal angles and base slightly wider than elytral one. Elytral interval 7 convex basally. Protarsomeres 1-3 dilated and with ventral pad in male. Body smaller, BL 5-5.4 mm. ................ 14. D. rufipes sp.n.

- Pronotum with sides more rounded in basal half than in front, with widely rounded basal angles and base distinctly wider than that of elytra. Elytral interval 7 costate basally. Protarsi barely dilated in male, with ventral pad absent from tarsomere 3. Body larger, BL 5.3-6.1 mm.

15. D. laticolle sp.n.

12. Elytral intervals almost flat in basal third. Median lobe of aedeagus with apex fairly long, internal sac unarmed (Figs 37-38).

12. D. bidoupense

- Elytral intervals convex. Median lobe of aedeagus with apex shorter, internal sac with a cluster of large teeth (Figs 35-36). 13. D. simile

\section{The blattoides-group}

REDESCRIPTION. Body elliptic, Amara-like, small- to medium-sized. Scape longer than antennomere 3, shorter to indistinctly longer than antennomere 4 , pedicel long, mean A2L/A3L ca $0.6-0.7$. Pronotum trapezoidal, broadest mostly less than a fourth from base, more than twice as wide as head, not or barely narrower than elytra, with wide basolateral lobes; lateral margin strongly explanate basally yet nonreflexed, with 0-2 setae. Elytral base slightly oblique; striae 1-7 joining basal ridge, which is arcuate and much higher at suture than at humeral angle. Terminal maxillary palpomere 1-1.4 times as long as penultimate one. Es3 fairly long. Legs: $t i 2$ and $t i 3$ with heavy spiny armature.

DIAGNOSIS. Body of nearly continuous elliptic outline following subequally very wide bases of pronotum and elytra. Apical maxillary palpomere mostly longer than penultimate one. Explanate lateral margin of pronotum very wide posteriorly and pale. Elytral stria 7 adjoining basal ridge. Legs: $f e 3$ glabrous; $t i 2$ externally with preapical seta; MT1L/MT2-4L $>1$.

The group includes four species.

\section{Dalatagonum blattoides Fedorenko, 2011} Figs 15, 43-44.

Fedorenko, 2011: 10 (Dalat Plateau, S-Vietnam).

MATERIAL. 21 specimens of the type series, including holotype $\sigma^{7}$ (ZMMU) labelled: 'S[outhern] Vietnam, Lam Dong Prov[ince]., Bi Doup - Nui Ba Nat[ure]. Res[erve]., $12^{\circ} 07 \mathrm{~N} /$ $108^{\circ} 39^{\prime} 20^{\prime \prime} \mathrm{E}$, Bi Doup Mt., N[orthern]. slope, $\mathrm{h}=1700-1900 \mathrm{~m}$, 10.IV.2008, leg. D.Fedorenko'.

REDESCRIPTION. Unnecessary except as follows. BL 6.4-7.7 mm. Dorsum reddish dark brown to nearly black; legs, explanate lateral margin of pronotum, elytral epipleura and abdominal sternite VII in apical 1/3-1/2, reddish-yellow; $c x 3$ infuscated; basal and apical margins of pronotum, scutellum, narrow lateral margin and usually also suture of elytra red. Microsculpture consisting of moderately transverse meshes, more superficial on elytra than on pronotum.

Head. Eyes slightly flattened, about twice as long as genae. Scape indistinctly shorter than antennomere 4. Apical maxillary palpomere indistinctly longer than penultimate one.

Pronotum more than half as wide as long, evenly rounded on sides, broadest close to base, much wider at base than at apex, with widely rounded basal angles. Base with median part straight and slightly broader than lateral lobes; the lobes projecting far, oblique posterolaterad, slightly rounded at posterior margin. 
352

D.N. Fedorenko

Lateral margin non-reflexed, lateral bead obsolete just before basal angle; setigerous pore about 5-7 pore diameters distant from lateral bead. Median line rather shallow, obsolete basally and apically. Basal transverse impression nearly indistinct.

Elytra about as wide as pronotum, each with 16 US. Basal ridge rather strongly arcuate.

Legs long, ta 3 slightly longer than $t i 3$, metatarsomere 1 barely longer than metatarsomeres $2-4 ; t i 2$ and $t i 3$ with the heaviest spiny armature in the genus, spiniform setae at anterolateral ridge much longer than width of the respective tibia, those at posterolateral ridge barely shorter; $t i 2$ with preapical seta. Tarsi bisulcate, inner sulcus being rather shallow in ta 3; pro- and mesotarsomere 4 with moderately long apical lobes.

Male T9 subtriangular basally (Fig. 15). Aedeagus median lobe with narrow bottom; apex medium-sized, narrow, with a small round capitulum (Figs 43-44). Female gonocoxte IX ventrally trisetose.

DIAGNOSIS. Easily recognizable within the group by large size, pale body colour, the bisetose pronotum, and heavily armed $t i 2$ and $t i 3$.

DISTRIBUTION. Only recorded in the Bi Dup - Dui Ba Nature Reserve, Lam Dong Province, southern Vietnam.

2. Dalatagonum ellipticum Fedorenko, 2011 Figs 8, 14, 45-46.

Fedorenko, 2011: 11 (Dalat Plateau, S-Vietnam).

MATERIAL. 16 specimens of the type series, including bolotype $O^{\top}$ (ZMMU) labelled: 'South Vietnam, Lam Dong Prov[ince].,
Bi Doug — Nui Ba Nat[ure]. Res[erve]., 12 $07^{\prime}$ N, 108 $399^{\prime 2} 20^{\prime \prime}$ E, Bi Loup Mt., Northern]. slope, $\mathrm{h}=1700-1900$ m, 12.IV.2008, leg. D.Fedorenko'

REDESCRIPTION. Unnecessary, except for the following differences from D. blattoides. Small, BL 4.3-4.9 mm. Pronotum with less extensive pale colour, elytra more extensively pale, including apex and wider sutural and lateral strips; pronotum often brown. Microsculpture subequally distinct on pronotum and elytra or more superficial on the former.

Frontal fovea almost indistinct. Scape long, distinctly longer than antennomere 4. Apical maxillary palpomere distinctly longer than penultimate one.

Pronotum almost parallel-sided in basal half. Apical bead very fine to subinterrupted medially, apical angles slightly more widely rounded. Lateral bead reaching basal angles. Setigerous pore about 3-4 pore diameters distant from lateral bead, the bead reaching basal angles. Median line distinct, mostly reaching base. Basal fovea indistinct. Elytra slightly shorter, with apex slightly wider relative to base; each elytron with 15 US. SSC adjoining stria 2.

Legs, especially tarsi, short; ta 2 much shorter than $t i 2$, ta 3 shorter than (sometimes as long as), ti; ti 2 and ti 3 less heavily armed, anterolateral spiniform setae longer than width of the respective tibia; pro- and mesotarsomere 4 rather strongly lobed, lobes half as long as tarsomere 5.

Male T9 wide and square basally (Fig. 14). Aedeagus median lobe (Figs 45-46): apex in lateral view tapered, large, triangular, in ventral view with a widely rounded tip. Female gonocoxite IX bisetose ventrally.
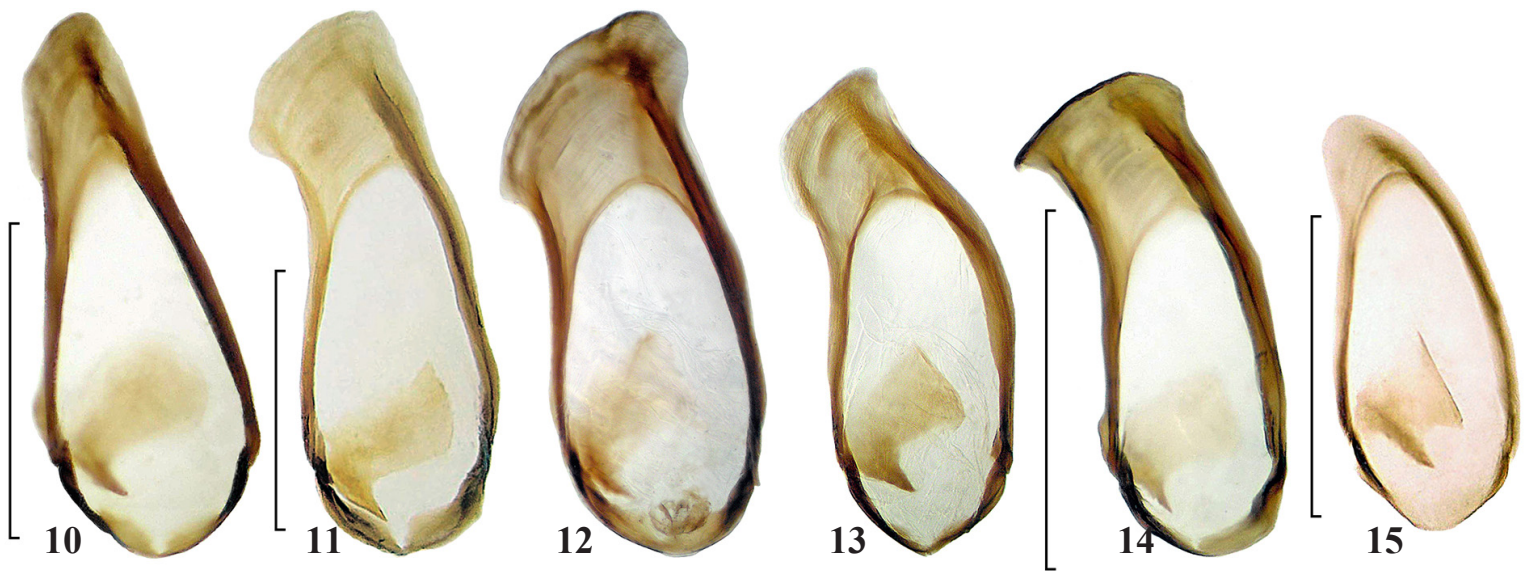

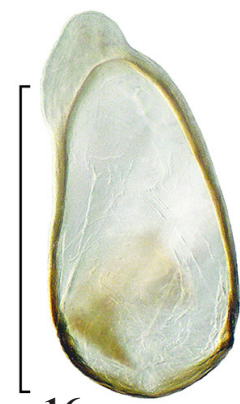

16

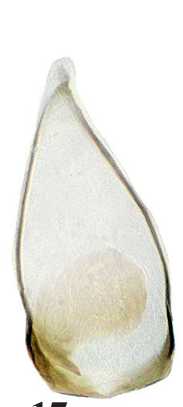

17

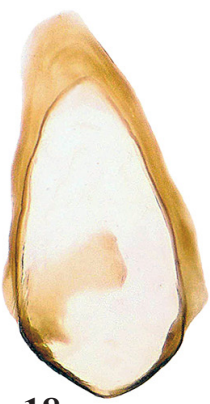

18

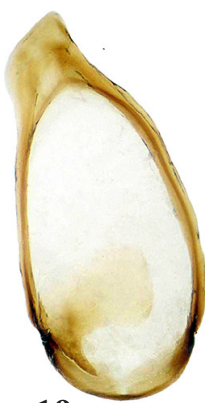

19

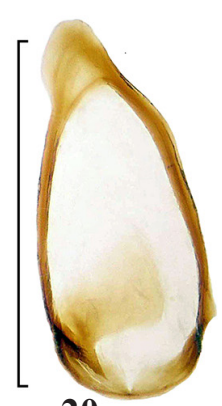

20

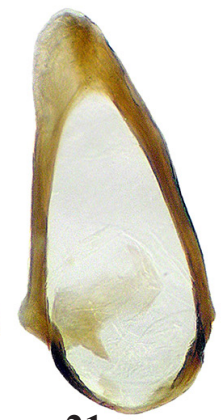

21

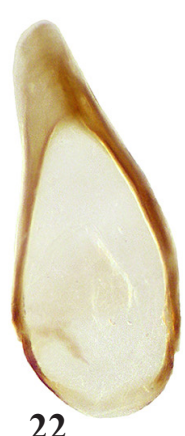

22

Figs 10-22. Male turgite IX, ventral aspect: 10 - Dalatagonum calathoides; 11 - D. elongatum; 12 - D. convexicolle sp.n.; 13 D. amariforme sp.n.; $14-$ D. ellipticum; $15-$ D. blattoides; $16-$ D. rotundatum sp.n.; $17-D$. quadrisetosum sp.n.; $18-D$. anichkini; 19 - D. simile; 20 - D. bidoupense; 21 - D. rufipes sp.n.; $22-$ D. laticolle sp.n. Scale bar - $1 \mathrm{~mm}$.

Рис. 10-22. Тергит IX самца, вентрально: 10 - Dalatagonum calathoides; 11 - D. elongatum; 12 - D. convexicolle sp.n.; 13 D. amariforme sp.n.; 14 - D. ellipticum; 15 - D. blattoides; $16-$ D. rotundatum sp.n.; 17 - D. quadrisetosum sp.n.; $18-$ D. anichkini; $19-$ D. simile; $20-$ D. bidoupense; $21-$ D. rufipes sp.n.; $22-$ D. laticolle sp.n. Масштаб - 1 мм. 
DIAGNOSIS. A small-sized species of the group with bisetose pronotum and rather pale body.

DISTRIBUTION. Only known from two close localities in the Bi Doup - Nui Ba Nature Reserve.

\section{Dalatagonum sericeum Fedorenko, 2011}

Fedorenko, 2011: 12 (Dalat Plateau, S-Vietnam).

MATERIAL. Holotype + (ZMMU): 'South Vietnam, Lam Dong Prov[ince]., Bi Doup - Nui Ba Nat[ure]. Res[erve]., $12^{\circ} 11^{\prime} \mathrm{N}$, $108^{\circ} 42^{\prime} \mathrm{E}, \sim 4 \mathrm{~km}$ SSE of Hon Giao Mt, $\mathrm{h}=1500-1700 \mathrm{~m}, 5 . \mathrm{V} .2008$, leg. D.Fedorenko.

REDESCRIPTION. BL $5.6 \mathrm{~mm}$. Dorsum black, legs red, coxae and femora except apices barely infuscated. Widely explanate lateral margin of pronotum translucent with red; elytral epipleura behind middle, reflexed lateral margin and apex along sides reddish-brown; epipleura otherwise brown. Microsculpture consisting of moderately transverse meshes on pronotum and very transverse meshes on elytra, giving the elytra sericeous and slightly iridescent luster.

Scape barely shorter than antennomere 4. Pronotum asetose. Body otherwise similar to that of D. ellipticum except as follows. Pronotum as in D. blattoides; base very wide, more than twice as wide as apex, with median part more than a fourth wider than lateral lobes. Apical bead very weak medially; lateral bead reaching basal angles; basal foveae as minute pits close to starting points of lateral lobes, with a small boss merging into disc anteriorly. Elytra each with 16 US. Striae deep, intervals convex on disc and very convex laterally and apically. Legs slightly longer except tarsi; $t i 2$ and $t i 3$ with spiny armature slightly heavier; metatarsomere 1 slightly longer than metatarsomeres 2-4.

DIAGNOSIS. Distinguishable within the group by small and dark body with the asetose pronotum.

DISTRIBUTION. Known from the type locality only.

\section{Dalatagonum amariforme Fedorenko, sp.n.}

Figs 1, 13, 47-48.

MATERIAL. Holotype $\sigma^{7}$ (ZMMU), labelled: 'Vietnam, Dak Lak Prov.[ince], Chu Yang Sin Natn. Park, $12^{\circ} 23^{\prime} 48^{\prime} \mathrm{N} / 108^{\circ} 20$ $59^{\prime \prime}$, Krong Kmar riv[er]., upper flow, $\mathrm{h}=1200-1650$ m, 30.III14.IV.2012, D. Fedorenko leg.'. Paratypes (SIEE, ZISP, ZMMU): $2 \sigma^{7} \sigma^{7}, 5$ 우, same data; 2 우, same data, except for $\mathrm{h}=1000 \mathrm{~m} ; 2 \sigma^{7} \sigma^{7}$, ㅇ, same except $108^{\circ} 21^{\prime} \mathrm{E}$ and 19.III-2.IV.2013.

DESCRIPTION. Body (Fig. 1), BL 5.7-6.3 mm. Head, pronotum and underside brown black; elytra black; palps, antennae, legs and apical margin of abdominal sternite VII reddish-yellow; mandibles, labrum and femora except apices red; pronotum with base narrowly, and explanate lateral margins widely translucent with red; scutellum, elytra along sides in apical two fifths, and often also prosternum and elytral epipleura reddish, elytral bases and suture less distinctly so. Microsculpture distinct on head and pronotum, consisting of isodiametric or transverse meshes, respectively; elytral microsculpture slightly more superficial, composed of very transverse meshes. Pronotum very finely and densely rugulose. Dorsum moderately shiny, pronotum slightly sericeous, elytra less so or with no sericeous lustre.

Head with indistinct frontal foveae and supraocular groove; eyes slightly flattened, gena about half as long as eye. Posterior supraocular seta on a level with posterior margin of eye. Scape distinctly shorter than antennomere 4 . Mandibles moderately long. Apical two maxillary palpomeres subequally long.

Pronotum bisetose on each side, trapezoidal, evenly rounded on sides, broadest a fourth from base, with rather narrowly rounded basal angles; disc flat basally, moderately convex apically. Base nearly twice as wide as apex, with median part slightly wider than lateral lobes; these very slightly produced, very slightly oblique posterolaterad. Apex entirely beaded, nearly truncate medially; apical angles porrect, subrectangular, rather sharp. Explanate lateral margin very wide basally, not or very slightly reflexed; lateral bead almost reaching basal angle. Median line fine, obsolete basally and apically. Basal foveae as shallow and short longitudinal depressions at starting points of basolateral lobes. Anterolateral setigerous pore foveate, inserted in the borderline between disc and explanate lateral margin, 2.7-3 pore diameters distant from lateral bead; posterolateral setigerous pore 4.4-5.2 pore diameters distant from basal angle. Basal transverse impression very shallow to indistinct, slightly convex apicad, area behind it finely and densely strigose and somewhat rugulose; apical transverse impression obliterate.

Elytra broadest about two fifths from base, with very narrowly rounded apices, each with 16-17 US. Basal ridge arcuate apicad, humeral angle acute. Striae impunctate, deep, more so apically and laterally. Parascutellar striole mostly entire and deep, sometimes shallow, occasionally obsolete. Intervals subequally wide basally, subconvex, convex before apex, 7th and 8th convex all along; interval 7 carinate just outside stria 6 in basal 1/3-2/5. SSc adjoining stria 2; base slightly oblique to humerus.

Underside smooth.

Legs moderately long, ti2 a fourth longer than $t a 2$, $t i 3$ slightly longer than $t a 3$; metatarsomere 1 slightly longer than metatarsomeres 2-4. Tibiae with anterolateral spiniform setae not (ti3) or barely ( $t i 2)$ longer than width of the tibia; $t a 2$ and $t a 3$ very shallowly bisulcate, protarsomere 1 only sulcate in female; pro- and mesotarsomere 4 conspicuously bilobed.

Male T9 with base wide and square (Fig. 13). Aedeagus median lobe (Figs 47-48) robust; apex very small, triangular, with narrowly rounded tip. Internal sac in apical half with two longitudinal clusters of large teeth. Female gonocoxite IX ventrally bisetose.

DIAGNOSIS. A member of the blattoides-group with quadrisetose pronotum and distinctive aedeagus.

DISTRIBUTION. Known from the type locality only, this species occurs at lower altitudes than the other congeners recorded in the Dalat Plateau (including the Dak Lak Plateau).

NAME. Refers to the similarity to Amara (s.str.), Zabrini, Carabidae, in appearance.

COMMENTS. Quadrisetose pronotum and very distinctive aedeagus separate this species from the other species of the blattoides-group. The first feature is certain to be primitive, suggesting the basalmost position of $D$. amariforme sp.n. within the group.

\section{The calathoides-group}

DESCRIPTION. Body oblong-oval to very slender ( $D$. broteroides). Dorsum black, explanate lateral margin of pronotum barely translucent with red or brown posterolaterally; tibiae and/or femora infuscated. Scape mostly barely shorter than antennomere 3 and distinctly shorter than antennomere 4 , pedicel mostly short, about half as long as antennomere 3 . Maxillary palpomere 4 slightly shorter than 3. Pronotum subquadrangular to obtrapezoidal, broadest distinctly or much before base; explanate lateral margin mostly wide at base, barely to strongly reflexed, with anterolateral seta (the seta occasionally absent from one specimen of $D$. convexicolle sp.n.). Elytra more or less elliptic, albeit fairly wide at bases; bases truncate to oblique inwards. Basal ridge strongly arcuate apicad, with both ends at the same level. Legs long, $t i 2$ externally bisetose or with preapical seta (D. elongatum); ti2 and $t i 3$ with moderately strong spiny armature; $f e 3$ with $0-1$ 
median anteroventral seta. Metatarsomere 1 as long as or slightly shorter than metatarsomeres $2-4$.

DIAGNOSIS. Body large-sized for the genus and darker coloured; pronotum-to-elytra outline interrupted by a distinct inward angle; apical maxillary palpomere short; pronotum bisetose and mostly obtrapezoidal, with basolateral lobes distinctly to much narrower than base in between; elytral stria 7 not quite reaching humerus; $t i 2$ and $t i 3$ moderately armed,

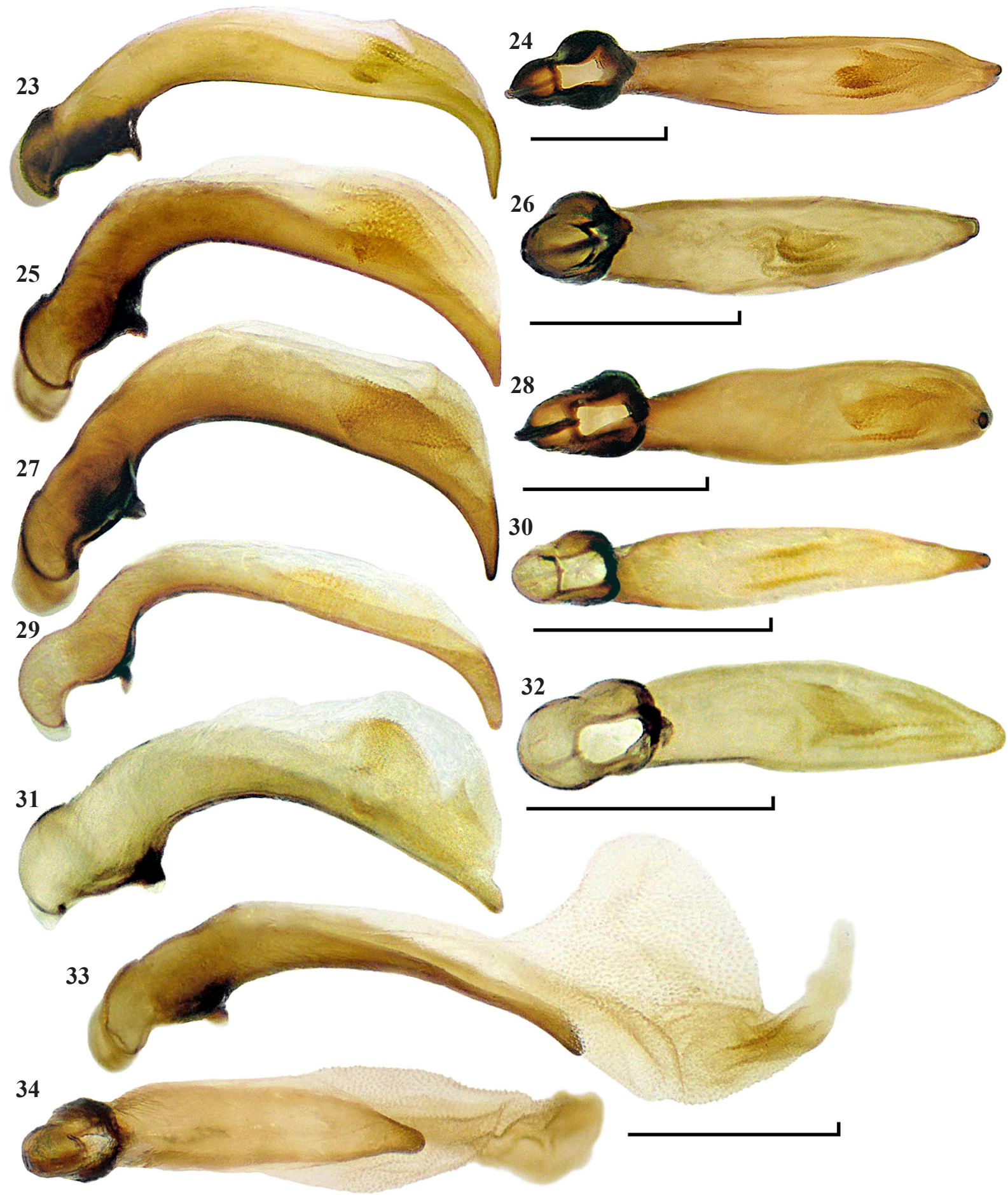

Figs 23-34. Median lobe of aedeagus: 23-24 - Dalatagonum elongatum; 25, 26 - D. calathoides; 27-28 - D. convexicolle sp.n.; 29-30 - D. quadrisetosum sp.n.; 31-32 - D. rotundatum sp.n.; 33-34 - D. anichkini; 23, 25, 27, 29, 31, 33 - left aspect; 24, 26, 28, $30,32,34$ - right aspect. Scale bar - $1 \mathrm{~mm}$.

Рис. 23-34. Средняя доля эдеагуса: 23-24 - Dalatagonum elongatum; 25, 26 - D. calathoides; 27-28 - D. convexicolle sp.n.; 2930 - D. quadrisetosum sp.n.; 31-32 - D. rotundatum sp.n.; 33-34 - D. anichkini; 23, 25, 27, 29, 31, 33 — вид слева; 24, 26, 28, 30, 32,34 - вид справа. Масштаб - 1 мм. 
ti 2 mostly bisetose externally, metatarsomere 1 barely shorter than metatarsomeres 2-4 combined.

DISTRIBUTION. Three $(D$. elongatum, D. calathoides, and $D$. convexicolle sp.n.) of totally four species of the group are known from a few close localities in the Dalat Plateau, including the Dak Lak Plateau, within Lam Dong, Khanh Hoa and Dak Lak provinces, southern Vietnam. D. broteroides is endemic to the Bi Doup Mt, the Dalat Plateau.
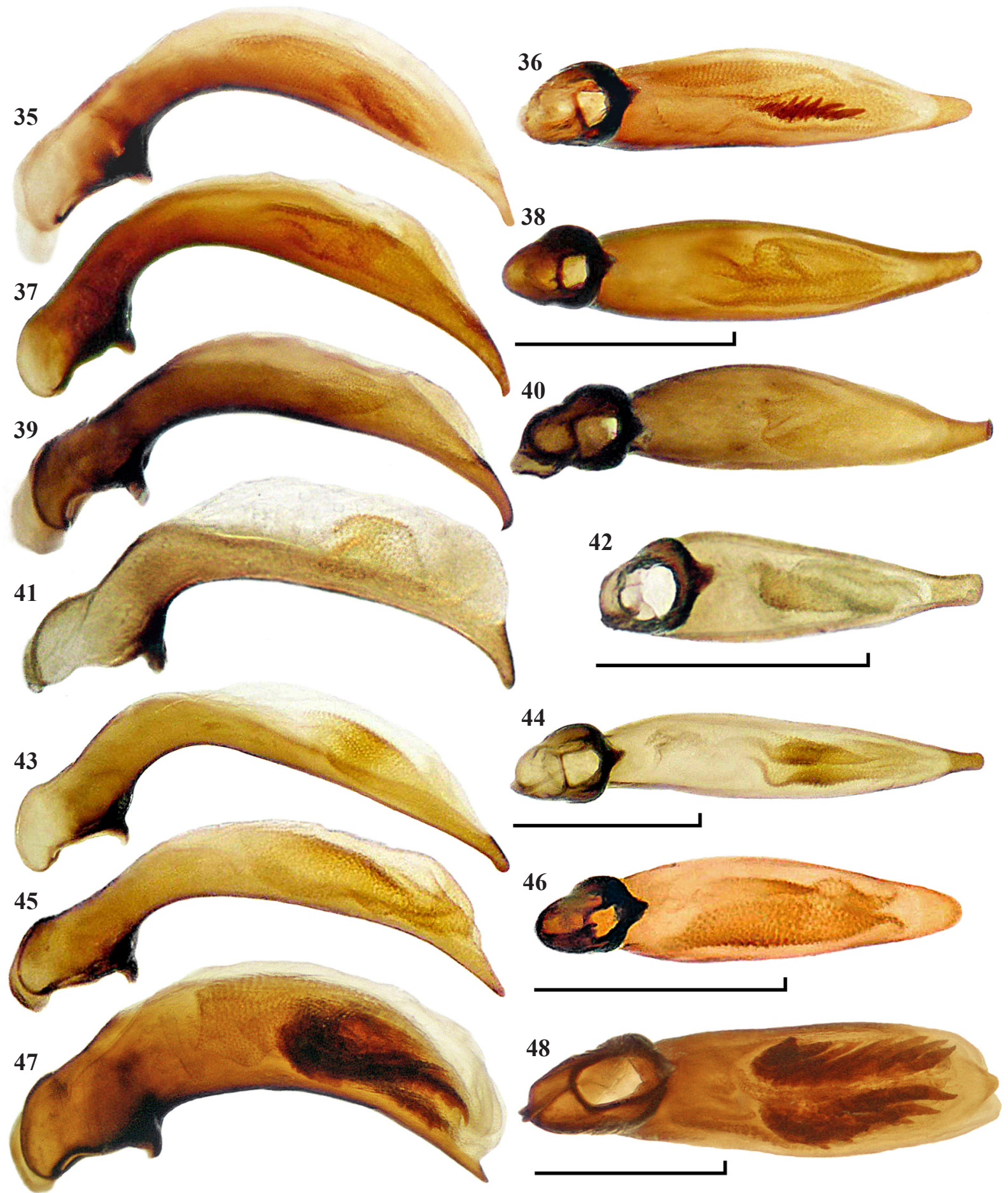

Figs 35-48. Median lobe of aedeagus: 35-36 - D. simile; 37-38 - D. bidoupense; 39-40-D. rufipes sp.n.; 41-42 - D. laticolle sp.n.; 43-44 - D. blattoides; 45-46 - D. ellipticum; 47-48 - D. amariforme sp.n.; 35, 37, 39, 41, 43, 45, 47 — left aspect; 36, 38, 40, 42, 44, 46, 48 - right aspect. Scale bar - $1 \mathrm{~mm}$.

Рис. 23-34. Средняя доля эдеагуса: 35-36 - D. simile; 37-38 - D. bidoupense; 39-40-D. rufipes sp.n.; 41-42 - D. laticolle sp.n.; 43-44 - D. blattoides; 45-46 - D. ellipticum; 47-48 — D. amariforme sp.n.; 35, 37, 39, 41, 43, 45, 47 — вид слева; 36, 38, 40, $42,44,46,48$ - вид справа. Масштаб - 1 мм. 


\section{Dalatagonum elongatum Fedorenko, 2011} Figs 11, 23-24.

Fedorenko, 2011: 13 (Dalat Plateau, S-Vietnam).

MATERIAL. 21 specimens of the type series, including holotype $\sigma^{7}$ (ZMMU): 'South Vietnam, Lam Dong Prov[ince]., Bi Doup - Nui Ba Nat[ure]. Res[erve]., 12 $12^{\circ} 10^{\prime} 44^{\prime \prime} \mathrm{N} 108^{\circ} 40^{\prime} 44^{\prime \prime} \mathrm{E}$, env. Long Lanh, h=1400-1600 m , 14-15.IV.2008, leg. D.Fedorenko.

Additional material. 19, Khanh Hoa Province, Hon Ba Mt, $\sim 1400 \mathrm{~m}$, IV.2003, leg. A. Borisenko; $10^{7}, 1$,, Vietnam, Dak Lak Province, Chu Yang Sin National Park, $12^{\circ} 22^{\prime} 40^{\prime \prime} \mathrm{N} 108^{\circ} 21^{\prime} 11^{\prime \prime} \mathrm{E}$, $1.5 \mathrm{~km} \mathrm{~W}$ of Chu Pan Phan Mt, h=1650 m, 30.III-11.IV.2012; 2 우, same data, except for $12^{\circ} 22^{\prime} 36^{\prime \prime} \mathrm{N} 108^{\circ} 21^{\prime} 13^{\prime \prime} \mathrm{E}, 19 . \mathrm{III}-2 . I V .2013$; 1 , , same data, except for $12^{\circ} 24^{\prime} 32^{\prime \prime} \mathrm{N} 108^{\circ} 23^{\prime} 17^{\prime \prime} \mathrm{E}, \sim 3 \mathrm{~km}$ W of Chu Yang Sin Mt, h=1500-1600 m, 15-30.V.2014.

REDESCRIPTION. Unnecessary except as follows. BL 8.5-10.4 mm. Dorsum shiny black, explanate lateral margin of pronotum translucent with brown; legs and sometimes also mandibles and labrum brown. Microsculpture distinct, consisting of very transverse meshes which are much smaller and more superficial on pronotum than on elytra.

Head. Frontal foveae mostly shallow yet distinct; eyes usually slightly to distinctly flattened, gena about a fourth as long as eye. Antennae long, surpassing pronotal base by segments 9-11; antennomere 3 slightly shorter than 4th, twice as long as pedicel. Mandibles long; apical maxillary palpomere a fifth shorter than penultimate one.

Pronotum obtrapezoidal, evenly rounded on sides, broadest about a third from base. Base with median part half to three fourths wider than lateral lobes; these, along with basal angles, very evenly rounded and produced far beyond base. Apex truncate or barely convex, with a fine bead, apical angles narrowly rounded and slightly projecting. Explanate lateral margin slightly yet abruptly reflexed, merged into fairly large, deep, round basal foveae; setigerous pore about three pore diameters distant from lateral bead. Lateral bead obliterated much before basal angle. Median line shallow to moderately deep, abbreviated basally and apically. Base (and sometimes also apex) often finely and densely strigose or rugulose. Basal and apical transverse impressions shallow, occasionally distinct.

Elytra each with 16 US. Base truncate, straight or slightly convex forward; basal ridge rather strongly arcuate apicad, with both ends at the same level; humeral angle distinctly behind level of humerus. Striae deep, increasingly so apicad. Intervals slightly convex basally, very convex before apex; 7 th and 8th very convex, basally narrower than 6th; 7th costate in basal third. $S S c$ mostly reaching basal ridge, morph with $S S c$ adjoining common base of striae 1 and 2 being frequent $(0.24, \mathrm{n}=25)$.

Legs: $f e 3$ glabrous; $t i 2$ and $t i 3$ about as long as respective tarsus, with a fairly weak spiny armature, anterolateral spiniform setae about as long as width of tibia; $t i 2$ externally with preapical seta; tarsomeres 1-3 bisulcate, with outer sulcus being deep (ta2) or traceable on tm 1 only (ta3) and inner sulcus shallow in ta 2 while indistinct or almost so in ta3; proand mesotarsomere 4 with fairly short apical lobes.

Male T9 strongly dilated at base (Fig. 11). Aedeagus median lobe with bottom moderately wide, subsinuate dorsally on left side; apex very long, narrow, strongly bent ventrad, pointed apically (Figs 23-24). Female gonocoxite IX bisetose ventrally.

DIAGNOSIS. The largest species of the genus, Calathuslike in appearance, with glabrous $f e 3$ and externally unisetose ti2.

\section{Dalatagonum calathoides Fedorenko, 2011} Figs 10, 25-26.

Fedorenko, 2011: 15 (Dalat Plateau, S-Vietnam).

MATERIAL. 14 specimens of the type series, including holotype $\sigma^{7}$ (ZMMU): 'South Vietnam, Lam Dong Prov., Bi Doup - Nui Ba Nat. Res., $12^{\circ} 07^{\prime}$ N, $108^{\circ} 39^{\prime} 20^{\prime \prime}$ E, Bi Doup Mt., N. slope, h=1700-1900 m, 19-22.IV.2008, leg. D.Fedorenko'.

Additional material. 2\$s, Vietnam, Dak Lak Province, Chu Yang Sin National Park, $12^{\circ} 22^{\prime} 36^{\prime \prime} \mathrm{N} 108^{\circ} 21^{\prime} 13^{\prime \prime} \mathrm{E}, 1.5 \mathrm{~km} \mathrm{~W}$ of Chu Pan Phan Mt, h=1650 m, 19.III-2.IV.2013, leg. D.Fedorenko.

REDESCRIPTION. Same as the previous species except as follows: Body smaller, BL 6.7-8.1 mm, dark brown to black, with slight or no iridescence. Legs red or reddishyellow, femora infuscated but bases and apices.

Eyes flattened, smaller, about twice as long as genae. Antennae long, surpassing pronotal base by more than segments 9-11. Scape as long as antennomere 3 and distinctly shorter than antennomere 4. Apical maxillary palpomere barely longer.

Pronotum less convex, slightly wider at base, barely more transverse, with basolateral lobes poorly rounded posteriorly, smaller and shorter than those of D. elongatum, and much narrower than median part of base. Apical angles barely projecting. Explanate lateral margin only slightly reflexed, with setigerous pore only $1.5-2$ pore diameters distant from lateral bead; lateral bead obsolete just before basal angles. Basal foveae very superficial to indistinct.

Elytra distinctly shorter, with bases oblique inwards; basal ridge very convex apicad, humeral angle slightly behind humerus, distinctly above the level of basal ridge at scutellum. Interval 7 very convex, in basal forth conspicuously narrower than 6 th.

Legs: $t i 2$ and ti3 moderately armed, with spiniform setae at outer margin barely longer than width of tibia; $t i 2$ externally bisetose (occasionally trisetose on one side); tarsomeres 12 (ta 1$)$ or tarsomeres $1-3$ ( $t a 2$ and $t a 3)$ bisulcate, mostly with outer sulcus being shallow to indistinct in ta3; fe3 with median anteroventral seta short to vestigial (unilateral in one specimen of the type series, absent from one of two female specimens from Chu Pan Phan Mt).

Male T9 subtriangular, slightly broadened basally (Fig. 10). Aedeagus median lobe (Figs 25-26) with moderately wide sclerotized bottom; apex triangular, curved ventrad, with apex blunt in ventral view. Female gonocoxite IX trisetose ventrally.

DIAGNOSIS. A medium-sized Calathus-like species distinctive within the group in having metafemoral seta, externally bisetose mesotibiae, and pronotal seta inserted close to the lateral edge.

\section{Dalatagonum convexicolle Fedorenko, sp.n.} Figs 2, 12, 27-28.

MATERIAL. Holotype $0^{7}$ (ZMMU) labelled: 'Vietnam, Dak Lak Prov[ince]., Chu Yang Sin Nat[io]n[al]. Park, $12^{\circ} 22^{\prime} 40^{\prime} \mathrm{N}$ $108^{\circ} 21^{\prime} 11^{\prime \prime} \mathrm{E}, 1.5 \mathrm{~km} \mathrm{~W}$ [of ] Chu Pan Phan Mt, h=1650 m, 30.III11.IV.2012, leg. D.Fedorenko'. Paratypes (SIEE, ZISP): $20^{7} 0^{7}, 5$, 9 , same data; $10^{\prime \prime}, 4$ 오, same data except $12^{\circ} 22^{\prime} 36^{\prime \prime} \mathrm{N} 108^{\circ} 21^{\prime} 13^{\prime \prime} \mathrm{E}$, 19.III-2.IV.2013; 1 을 same data except $12^{\circ} 24^{\prime} 32^{\prime \prime} \mathrm{N} 108^{\circ} 23^{\prime} 17^{\prime \prime} \mathrm{E}$, $\sim 3 \mathrm{~km}$ W [of ] Chu Yang Sin Mt, h=1500-1600 m, 15-30.V.2014; +, 'South Vietnam, Lam Dong Prov[ince]., Bi Doup - Nui Ba Nat[ure]. Res[erve]., $12^{\circ} 10^{\prime} 44^{\prime \prime} \mathrm{N}, 108^{\circ} 40^{\prime} 44^{\prime \prime} \mathrm{E}$, env. Long Lanh, $\mathrm{h}=1400-1600 \mathrm{~m}, 17-18 . I V .2008$, leg. D.Fedorenko.

DESCRIPTION. Body (Fig. 2) shiny black, BL 6.9-8.3 $\mathrm{mm}$. Explanate lateral margins of pronotum more or less distinctly translucent with brown, pronotal base very narrowly translucent with red. Tarsi and usually also apical margin of abdominal sternite VII pale red or reddish-yellow, femora 
dark brown except apices, tibiae reddish brown. Labrum and mandibles dirty red but apices infuscated. Microsculpture highly superficial, partly obliterate, consisting of moderately transverse meshes on pronotal disc; elytra with very transverse yet distinct microsculpture and thence very slightly sericeous and faintly iridescent.

Eyes slightly to rather strongly flattened, about twice as long as genae. Posterior supra-ocular seta on a level with posterior margin of eye. Frontal foveae vague, followed by several shallow pores forming an ill-defined, uneven, U- or $\mathrm{V}$-shaped impression. Antennae surpassing pronotal base by apical 2-2.5 segments; scape barely shorter than antennomere 3 and distinctly shorter than antennomere 4. Apical maxillary palpomere as in the previous species.

Pronotum trapezoidal, short, much wider than head, well rounded on sides, broadest a third from base. Base much broader than apex, with median part broader than lateral lobes; lateral lobes, along with basal angles, projecting beyond base and rather widely rounded, barely less so at posterior margin. Apical angles blunt, slightly projecting; apical bead fine. Explanate lateral margin narrow before seta, very wide basally, gently yet distinctly reflexed, separated from convex disc by a lightly impressed line, occasionally nonreflexed; setigerous pore 3.5-5 pore diameters distant from lateral edge. Basal foveae large, rounded, rather shallow to indistinct. Lateral bead obsolete just or well before basal angles. Basal and apical transverse impressions indistinct or shallow and barely angulate forward. Disc mostly very finely and densely transversely rugulose.

Elytra oblong-oval to ovate, each with 16 US. Base subtruncate, varying from oblique slightly outwards to slightly inwards; basal ridge almost semicircular, with both ends at the same level. Extreme apices separated and narrowly rounded or blunt. Striae deep, deeper before apex and towards lateral margin. Parascutellar striole indistinct to deep yet slightly shortened anteriorly. Intervals (sub)convex, slightly more convex before apex; 7 th and 8 th often very convex. SSc mostly separated from stria 2 .

Underside smooth. Legs: $t i 2$ and $t i 3$ hardly longer than respective tarsi; $t i 2$ and $t i 3$ with spiny armature barely weaker than that of $D$. calathoides; $t i 2$ externally bisetose; tarsomeres 1-3 bisulcate; pro- and mesotarsomere 4 with apical lobes slightly longer than those of $D$. calathoides; $f e 3$ glabrous.

Male T9 square basally (Fig. 12). Aedeagus median lobe as in D. calathoides (Figs 27-28), except longer and narrower apex. Female gonocoxite IX trisetose ventrally.

DIAGNOSIS. Distinctive within the group in having the body medium-sized, $f e 3$ glabrous, $t i 2$ bisetose externally, pronotum convex, trapezoidal, transverse, and fairly large, with seta distant rather far from lateral edge.

\section{Dalatagonum broteroides Fedorenko, 2011}

Fedorenko, 2011: 18 (Dalat Plateau, S-Vietnam).

MATERIAL. Holotype, teneral + (ZMMU): 'South Vietnam, Lam Dong Prov[ince]., Bi Doup - Nui Ba Nat[ure]. Res[erve]., $12^{\circ} 07^{\prime} \mathrm{N} 108^{\circ} 39^{\prime} 20^{\prime \prime} \mathrm{E}$, Bi Doup Mt, N[orthern]. slope, $\mathrm{h}=1700$ 1900 m, 16.IV.2008, leg. D.Fedorenko'.

REDESCRIPTION. Body slender due chiefly to narrow head and pronotum, BL $8.6 \mathrm{~mm}$. Rather pale brown, head brown, pronotum dark brown, explanate lateral margin translucent with reddish-yellow; mandibles infuscated apicad. Legs reddish-yellow, femora almost indistinctly infuscated (fairly pale body colour is due to teneral condition of the only specimen). Microsculpture distinct, consisting of very transverse meshes on pronotum and larger, slightly to strongly transverse meshes on elytra.
Head: eyes very small and flat, as long as genae, posterior supra-ocular seta much behind posterior margin of eye; frontal foveae short and shallow. Antennae long, surpassing pronotal base by segments 9-11, scape slightly shorter than antennomere 3 and distinctly shorter than antennomere 4 . Apical maxillary palpomere distinctly shorter than penultimate one. Mandibles very long.

Pronotum subquadrate and very narrow, evenly rounded on sides, broadest before middle, with basal angles rounded off. Base barely wider than apex, with median part much wider than almost indistinct lateral lobes. Apex truncate, very finely beaded; apical angles rounded, slightly projecting. Explanate lateral margin narrow in apical half, slightly wider and strongly reflexed behind, separated by distinct lateral groove from convex disc; the groove deep basally, reaching base, running just outside large and shallow basal foveae. Lateral bead obliterate in basal fourth. Setigerous pore about 2.7 pore diameters distant from lateral edge. Median line fine, deep basally, obsolete in second quarter (counting forward), obliterate apically.

Elytra elliptic, nearly parallel-sided in middle third, broadest behind middle, with a small re-entrant angle between rounded apices; each with 16 US. Base narrow, oblique inwards; basal ridge very convex apicad, its inward end slightly below the level of humeral angle. Striae subequally deep, intervals almost flat, outer ones convex behind middle; 7 th subcarinate along stria 6 in basal half. Left parascutellar striole entire, right one abbreviated in its anterior third. Metepisternum shortest within the genus.

Legs moderately long, ti2 and ti3 as long as respective tarsi; spiny armature weak, with anterolateral setae barely (ti2) or distinctly (ti3) shorter than width of the respective tibia; ti2 externally bisetose; tarsomeres 1-3 bisulcate, inner sulcus being very shallow in ta3; pro- and mesotarsomere 4 with very short apical lobes; fe3 with median anteroventral seta, $\operatorname{tr} 3$ with vestigial seta.

DIAGNOSIS. A very slender, Europhilus-like species distinctive within the group in having the head narrow, with small and flat eyes, and pronotum very narrow, broadest before middle, with narrow yet strongly reflexed lateral margin.

\section{The anichkini-group}

DESCRIPTION. BL 5.4-6.3 mm, shiny black, explanate lateral margin barely translucent with brown red. Scape as long as antennomere 3 and distinctly shorter than antennomere 4, pedicel about three fifths as long as antennomere 3 . Maxillary palpomere 4 longer than 3 . Pronotum with base less than 1.5 times as wide as apex and broadest mostly closer to middle; base with median part slightly to distinctly broader than lateral lobes; explanate lateral margin moderately wide at base, with 1-2 setae. Basal ridge truncate, with both ends at the same level. Legs moderately long: $t i 2$ and $t i 3$ with moderately strong spiny armature.

DIAGNOSIS. As for the previous group, except for the following points: body small, apical maxillary palpomere longer than penultimate one, pronotum subquadrate, small, broadest before or just behind middle; $f e 3$ externally glabrous; $t i 2$ externally bisetose.

The group includes three species from northern and central Vietnam.

\section{Dalatagonum anichkini Fedorenko, 2011} Figs 7, 18, 33-34.

Fedorenko, 2011: 17 (Ngoc Linh Mt, central Vietnam).

MATERIAL. Holotype $\sigma^{7}$ (ZMMU): 'Central Vietnam, Kon Tum Prov[ince]., N[orthern]. part, Ngoc Linh Nat[ure]. Reserve, 
Ngoc Linh env., pitfall trap V.2006, leg. A Anichkin'. - The original label data is here corrected to: ' $\ldots 2-3 \mathrm{~km} \mathrm{~W}$ of Ngoc Linh Mt., $15^{\circ} 05^{\prime} \mathrm{N} 107^{\circ} 57^{\prime} \mathrm{E}, \mathrm{h}=1600-2150 \mathrm{~m}$, pitfall traps, 19 .III-9.IV $2006, \ldots$...

REDESCRIPTION. Body (Fig. 7), BL 5.6 mm. Dorsum black, elytra slightly sericeous and iridescent; pronotum with base and explanate lateral margins slightly translucent with reddish, legs reddish-yellow, coxae and femora infuscated, except for bases and apices. Microsculpture very superficial, consisting of very transverse meshes on pronotum and extremely transverse meshes mixed with dense transverse lines, on elytra.

Genae about a fourth as long as flattened eyes. Frontal foveae short, shallow, extended onto sides of clypeus. Posterior supra-ocular seta on a level with posterior margin of eye. Antennae surpassing pronotal base by segments $10-11$. Apical maxillary palpomere barely longer than penultimate one.

Pronotum bisetose, fairly convex, subquadrate, equally rounded on sides, broadest just behind middle, with basal angles rounded off. Base broader than apex, with median part a fourth wider than lateral lobes; the lobes fairly small, evenly rounded, a little projecting. Apex truncate, entirely beaded; apical angles widely rounded, barely projecting. Explanate lateral margin very narrow in apical half, very wide and barely reflexed behind; lateral bead obsolete just before basal angles; lateral setigerous pore about one pore diameter distant from lateral bead. Basal foveae large yet very shallow anteriorly, becoming deep round pits close to base, with a small weak boss just outside. Median line deep medially, vague basally and apically. Basal transverse impression very shallow, apical transverse impression missing.

Elytra elliptic, broadest medially, with extreme apices rounded and slightly separated; each elytron with 16 US Basal ridge rather strongly arcuate, with both ends being at the same level. Striae subequally deep throughout, shallow basally, 6th and 7th obliterate just behind base. Intervals slightly convex, subequally wide. Parascutellar striole obliterate. $S S c$ about two pore diameters distant from basal ridge.

Legs: $t a 2$ and $t a 3$ shorter than respective tibiae; $t i 2$ not heavily armed, anterolateral setae about as long as width of the tibia; $t i 3$ with unmodified, thin and short, setae along antero- and posterolateral ridges; ti2 externally with 1-2 setae; tarsomeres 1-2 (ta 1) or 1-3 (ta2 and ta 3 ) bisulcate; pro- and mesotarsomere 4 with moderately long apical lobes. Metatarsomere 1 shorter than metatarsomeres 2-4.

Male T9 subtriangular, slightly dilated basally (Fig. 18). Aedeagus median lobe slightly arcuate, with narrow bottom; apex fairly small, subtriangular, its tip in ventral view rather widely rounded (Figs 33-34)

DIAGNOSIS. Very distinctive from the other species of the group in having pronotum bisetose, subquadrate and fairly large.

DISTRIBUTION. Known from the type locality only.

HABITATS AND HABITS. No data except that the holotype has been collected by pitfall trapping in a monsoon forest.

\section{Dalatagonum rotundatum Fedorenko, sp.n.} Figs 3, 16, 31-32.

MATERIAL. Holotype $\sigma^{7}$ (ZMMU) and paratypes, $20^{7} \sigma^{7}$, 4 우워 (SIEE) labelled: 'Vietnam, Kon Tum Prov[ince]., Kon Plong Distr[ict]., $14^{\circ} 45^{\prime} \mathrm{N} 108^{\circ} 18^{\prime} 10^{\prime} \mathrm{E}$, env. Ngok Boc $1 \mathrm{Mt}$., h=12001300 m, 8-23.IV.2015, D. Fedorenko leg.'

DESCRIPTION. As for D. anichkini, except as follows (some specimens of the type series are teneral and thence more or less brown coloured): Body (Fig. 3), BL 5.4-6.3 $\mathrm{mm}$. Femora slightly infuscated. Microsculpture very superficial yet traceable over pronotal disc, consisting of very transverse meshes; elytral microsculpture less distinct, consisting of extremely narrow transverse meshes mixed with transverse lines here and there.

Eyes slightly more convex. Antennae long, surpassing pronotal base by segments 9-11.

Pronotum bisetose, moderately convex, subquadrate, almost twice as wide as head, strongly rounded on sides, broadest just behind middle, with very widely rounded, hardly traceable basal angles. Base wider than apex, its median part a third wider than almost evenly rounded lateral lobes in general. Apical angles rounded yet distinctly projecting. Basal foveae with smaller and deeper pit at bottom and no boss outside.

Elytra ovate, broadest a third from base, with extreme apices slightly separated; sides strongly rounded behind humeri, less so in apical half; each elytron with 14-16 US. Striae subequally very deep. Intervals convex, outer ones slightly more convex and narrower. Parascutellar striole entire. $S S c$ close to basal ridge, separated from stria 2.

Legs: $t i 2$ externally bisetose; tarsomeres 1-2 (ta1) or 1-3 (ta 2 and $t a 3$ ) bisulcate; pro- and mesotarsomere 4 with fairly long apical lobes. Metatarsomere 1 varying from slightly shorter to slightly longer than metatarsomeres $2-4$ combined. Protarsi hardly dilated in male, with ventral pad absent from tarsomere 3 .

Male T9 robust, with rather wide sclerotized bottom (Fig. 16). Aedeagus median lobe robust, arcuate, with rather a wide bottom; apex small, widely subtriangular in ventral view (Figs 31-32). Female gonocoxite IX trisetose ventrally.

DIAGNOSIS. Distinctive in having the body robust, pronotum and elytra rather strongly rounded on sides; pronotum transverse, bisetose, much broader than head, with apical angles projecting and lateral margin slightly yet distinctly reflexed. Protarsi barely dilated in male, with ventral pad absent from $t m 3$, are what this species shares with no congener other than the sympatric species $D$. laticolle sp.n.

NAME. Refers to strongly rounded pronotum and elytra.

DISTRIBUTION. Known from the type locality only.

\section{Dalatagonum quadrisetosum Fedorenko, sp.n.} Figs 4, 17, 29-30.

MATERIAL. Holotype $O^{7}$ (ZMMU): 'N[orthern]-Vietnam, $\sim 45$ $\mathrm{km} \mathrm{W}$ of Hanoi, Ba Vi Nat[io]n[al]. Park, $21^{\circ} 04^{\prime} \mathrm{N} / 105^{\circ} 21^{\prime} 38^{\prime \prime} \mathrm{E}$, leaf-litter, $\mathrm{h}=1050-1100 \mathrm{~m}, 18 . \mathrm{VI} .2014$, D.Fedorenko leg.' Paratypes, 2 우 (SIEE), taken together with the holotype.

DESCRIPTION. As for D. anichkini except as follows: Body (Fig. 4), BL 5.8-6 mm. Dorsum black, elytra slightly iridescent, pronotum with narrower parts translucent with reddish. Microsculpture highly superficial, consisting of very dense transverse lines not forming meshes.

Eyes slightly more convex. Mandibles of normal shape, neither slender nor elongated. Antennae moderately long, surpassing pronotal base by apical 2.5 segments. Apical maxillary palpomere conspicuously longer than penultimate one.

Pronotum quadrisetose, flattened, and smaller, broadest before middle; sides rounded about two thirds from base, straight behind, with basal angles very obtuse and blunt yet distinct. Base broader than apex, its median part half to three fifths wider than small and posteriorly rounded lateral lobes. Apical angles projecting. Setigerous pores about one pore diameter distant from lateral edge. Basal foveae each with smaller yet deeper pit at bottom, with no boss outside.

Elytra each with 15 US. Parascutellar striole entire. SSc adjoining stria 2 or common base of striae 1 and 2 close to basal ridge. 
Legs: $t a 3$ shorter than $t i 3$, ta 2 barely shorter than $t i 2$, Metatarsomere barely shorter than metatarsomeres 2-4 combined; $t i 2$ with anterolateral setae shorter than width of the tibia, bisetose externally; pro- and mesotarsomere 4 with moderately long apical lobes.

Male T9 very narrow basally (Fig. 17). Aedeagus median lobe very slender, with very narrow sclerotized bottom; apex very long, subcylindric, strongly bent ventrad, with rounded tip (Figs 29-30). Female gonocoxite IX ventrally trisetose.

DIAGNOSIS. Distinctive in having pronotum small, subquadrate, and quadrisetose, with sides straight in front of distinct basal angles.

NAME. Refers to the quadrisetose pronotum.

DISTRIBUTION. Known from the type locality only.

HABITATS AND HABITS. All the specimens were captured by hands in leaf-litter.

\section{The bidoupense-group}

DESCRIPTION. BL 4.9-6.1 mm. Scape slightly shorter than antennomere 4, pedicel fairly long. Maxillary palpomere 4 mostly distinctly longer than palpomere 3 . Pronotum bisetose, (ob)trapezoidal, broadest closer to base, with fairly wide basolateral lobes; explanate lateral margin wide basally, not or indistinctly reflexed. Elytra elliptic to slightly ovate, with bases rather wide and barely oblique to humeri. Basal ridge arcuate apicad, with both ends at the same level. Legs long, ti2 and ti3 all along (D. convexicolle sp.n.) or in basal half with strong anterolateral setae; $f e 3$ externally with $0-1$ median anteroventral seta. Metatarsomere 1 more or less longer than metatarsomeres 2-4 combined. Female gonocoxite IX bisetose ventrally.

DIAGNOSIS. As for the calathoides-group, except for body small; apical maxillary palpomere longer than penultimate one, elytral stria 7 basally joining stria 9; pronotum slightly shorter, barely narrower than elytra, with basolateral lobes about as long as median part of base; $t i 2$ and $t i 3$ heavily armed, $t i 2$ externally with preapical seta, metatarsomere 1 longer than metatarsomeres 2-4 combined; $f e 3$ glabrous.

The group includes four species: $D$. bidoupense, $D$. simile, D. rufipes sp.n., and D. laticolle sp.n.

\section{Dalatagonum bidoupense Fedorenko, 2011} Figs 20, 37-38

Fedorenko, 2011: 19 (Dalat Plateau, S-Vietnam).

MATERIAL. Eight specimens of the type series, including holotype $0^{7}$ (ZMMU): 'South Vietnam, Lam Dong Prov[ince]., B Doup - Nui Ba Nat[ure]. Res[erve]., $12^{\circ} 07^{\prime} \mathrm{N} 108^{\circ} 39^{\prime} 20^{\prime \prime} \mathrm{E}, \mathrm{Bi}$ Doup Mt, N[orthern]. slope, $h=1700-1900$ m, 12.IV.2008, leg. D.Fedorenko',

REDESCRIPTION. BL 4.9-5.6 mm. Dorsum black to piceous, with pronotal lateral margin and base slightly translucent with reddish-brown; labrum reddish-brown; legs reddish-yellow to red, with coxae and femora except bases and apices dark brown to black. Microsculpture consisting of transverse meshes, superficial yet distinct throughout or less distinct on elytra.

Eyes, combined with fairly short genae, rather convex. Frontal foveae as short and shallow yet rather distinct impressions just behind clypeus, often enclosing a transverse rectangular to pentagonal area adjacent to clypeus. Antennae moderately long, surpassing pronotal base by segments 10-11. Mandibles moderately long. Maxillary palpomere 4 slightly longer than palpomere 3.

Pronotum convex, obtrapezoidal, broadest two fifths from base, barely narrower than elytra; sides evenly rounded or less so behind middle, slightly converging toward very wide- ly rounded, just indicated, basal angles. Base moderately wide, with rather narrow lateral lobes; the lobes fairly large, projecting, slightly oblique posterolaterad and more or less rounded. Apex barely convex, with narrowly rounded and very slightly projecting apical angles; apical bead entire, extremely fine or obliterate medially. Lateral margin very widely explanate in basal half, not or indistinctly reflexed; setigerous pore impressed, two pore diameters distant from lateral bead. Lateral bead obliterate just before base. Median line fine, usually reaching base and obliterate close to apex. Basal foveae and transverse impressions indistinct.

Elytra elliptic, with apices contiguous and rounded combined to barely separated by almost indistinct re-entrant angle; each elytron with 15 US. Striae deep, deeper apically and laterally, barely shallower basally. Intervals almost flat just behind basal ridge, increasingly convex apicad and laterad, 7th and 8th convex throughout, 7th basally narrower and more convex than 6th. Parascutellar striole entire to totally reduced.

Legs: $t a 2$ much shorter than $t i 2, t a 3$ slightly shorter than $t i 3$; $t i 2$ and $t i 3$ rather heavily armed in basal half, spiniform setae longer than width of respective tibia; tarsomeres 1-2 (tal) or 1-3 ( $t a 2$ and $t a 3$ ) bisulcate, protarsomere 2 being almost indistinctly sulcate; pro- and mesotarsomere 4 with fairly long apical lobes. Metatarsomere 1 barely longer than metatarsomeres 2-4 combined. Protarsomeres 1-3 dilated and with ventral pad in male.

Male T9 with base slightly dilated on right side (Fig. 20). Aedeagus median lobe with wide bottom; apex long, tapered, barely curved ventrad just before tip; tip in ventral view narrowly rounded (Figs 37-38)

DIAGNOSIS. A Calathus-like species distinctive within the group chiefly in having infuscated femora, combined with protarsomeres 1-3 dilated in male.

DISTRIBUTION. Known from two close localities in the Bi Doup - Nui Ba Nature Reserve, the Dalat Plateau.

\section{Dalatagonum simile Fedorenko, 2011} Figs 19, 35-36.

Fedorenko, 2011: 20 (Dalat Plateau, S-Vietnam).

MATERIAL. Holotype $\sigma^{7}$ (ZMMU): 'South Vietnam, Lam Dong Prov[ince]., Bi Doup — Nui Ba Nat[ure]. Res[erve]., $12^{\circ} 07^{\prime} \mathrm{N}$ $108^{\circ} 39^{\prime} 20^{\prime} \mathrm{E}$, Bi Doup Mt, N[orthern]. slope, $\mathrm{h}=1700-1900 \mathrm{~m}$, 12.IV.2008, leg. D.Fedorenko'.

Additional material. $10^{\top}$ (ZISP), same exact locality: Lac Duong Distr., Bi Doup - Nui Ba Nat. Res., 2 km N of Bi Doup Mt. [peak], $12^{\circ} 06^{\prime} 42^{\prime \prime N} 108^{\circ} 39^{\prime} 33^{\prime \prime} \mathrm{E}$, Bi Doup Mt, N[orthern]. slope, $\mathrm{h}=1700$ 2000 m, 7-16.IV.2008, A.V.Abramov leg. (Exp. of Russ.-Vietnam. Tropical Centre).

REDESCRIPTION. Same as the previous species, except for the following smallest differences if any. BL $5.6 \mathrm{~mm}$. Dorsum and femora dark brown, pronotum paler but disc. Antennal scape as long as antennomere 4. Apical maxillary palpomere barely longer. Pronotum slightly narrower apically, with more rounded sides. Elytral striae deeper, deep basally; intervals convex basally, very convex before apex. Metatarsomere 1 barely shorter.

Male T9 with base truncate and square (Fig. 19). Aedeagus median lobe as in D. bidoupense, except for blunt and short apex (Figs 35-36); internal sac with a compact cluster of about ten large teeth.

DIAGNOSIS. No differences from $D$. bidoupense other than distinctive aedeagus.

DISTRIBUTION. Known from the type locality only.

COMMENTS. Identification of the non-type specimen is provisional because of its aedeagus lost through collecting. 


\section{Dalatagonum rufipes Fedorenko, sp.n.}

Figs 5, 21, 39-40.

MATERIAL. Holotype $\sigma^{7}$ (ZMMU) labelled: 'Vietnam, Dak Lak Prov[ince]., Chu Yang Sin Nat[io]n[al]. Park, $12^{\circ} 22^{\prime} 36^{\prime \prime} \mathrm{N}$ $108^{\circ} 21^{\prime} 13^{\prime \prime} \mathrm{E}, 1.5 \mathrm{~km} \mathrm{~W}$ [of ] Chu Pan Phan Mt, h=1650 m, 19.III2.IV.2013, leg. D.Fedorenko.' Paratypes (SIEE): $2 \sigma^{7} \sigma^{7}$, same data; $20^{7} \sigma^{7}, 1$, same data except $12^{\circ} 22^{\prime} 40^{\prime \prime} \mathrm{N} 108^{\circ} 21^{\prime} 11^{\prime \prime} \mathrm{E}, 30$.III11.IV.2012.

DESCRIPTION. Very similar to D. bidoupense except the following differences: Body (Fig. 5), BL 5-5.4 mm. Dorsum shiny black or brown black, elytra slightly sericeous and barely iridescent; pronotum along explanate lateral margins slightly translucent with reddish-brown; labrum reddish-brown; mouthparts, antennae and legs reddish-yellow to red. Microsculpture superficial, consisting of very transverse meshes on elytra.

Maxillary palpomere 4 distinctly longer than 3 .

Pronotum barely wider and barely narrower than elytra, broadest closer to base due chiefly to its sides running parallel in basal half and not or barely converging basad; basal angles rounded yet rather distinct. Base wide, almost twice as wide as apex, with median part as wide as lateral lobes. Apex truncate between projecting angles with blunt tips. Borderline between disc and non-reflexed lateral margin hardly traceable just behind lateral seta; setigerous pore well impressed, $4.5-5$ pore diameters distant from lateral bead; lateral bead reaching or almost reaching base. Median line fine, not quite reaching base, obliterate apically. Basal foveae very small and shallow, transverse impressions indistinct or almost so.

Elytra shorter, with humeri minutely denticulate. Intervals almost flat to slightly convex on disc, convex laterally (7th and 8th) and apically, 7th basally slightly narrower than 6th. Parascutellar striole mostly vestigial, shallow and obliterate near basal ridge. SSc separated from stria 2. Metepisternum shorter.

Legs: tarsomere 1 (tal) or tarsomeres 1-2 (ta2 and ta3) bisulcate. Metatarsomere 1 distinctly longer than metatarsomeres 2-4 combined. Protarsomeres 1-3 dilated and with ventral pad in male.

Male T9 triangular, widely rounded at base (Fig. 21). Aedeagus median lobe as in D. bidoupense, except that apex is narrower and rostrate just apically (Figs 39-40).

DIAGNOSIS. A Calathus-like species distinctive within the group in having legs entirely red, pronotum parallelsided in basal half, and both apical maxillary palpomere and metatarsomere 1 long. Minutely toothed humeri are unique feature within the genus. Great similarity between $D$. rufipes sp.n. and $D$. bidoupense in the shape of the aedeagus and of the body suggests close relationships between the species.

DISTRIBUTION. Known from the type locality only.

NAME. Refers to the leg colour.

\section{Dalatagonum laticolle Fedorenko, sp.n.} Figs 6, 22, 41-42.

MATERIAL. Holotype $\sigma^{7}$ (ZMMU) labelled: 'Vietnam, Kon Tum Prov[ince]., Kon Plong Distr[ict]., $14^{\circ} 45^{\prime} \mathrm{N} / 108^{\circ} 18^{\prime} 10^{\prime \prime} \mathrm{E}$, env. ngok Boc 1 Mt., h=1200-1300 m, 8-23.IV.2015, D. Fedorenko leg.'. Paratypes $20^{\top} \sigma^{7}, 3$, $9+$ (SIEE), including 1 iq without head, same data; 1 , s, same data, except for $14^{\circ} 45^{\prime} \mathrm{N} / 108^{\circ} 17^{\prime} 51^{\prime \prime} \mathrm{E}, \mathrm{h}=1300$ $1400 \mathrm{~m}, 8-10 . \mathrm{IV} .2016$.

DESCRIPTION. Body (Fig. 6), BL 5.3-6.1 mm. Dorsum (brown) black, pronotum slightly reddish along basal margin, with explanate lateral margin more or less widely translucent with red; labrum, fine elytral reflexed margin and apices along sides red; elytral bases and suture often slightly reddish; legs reddish-yellow. Microsculpture consisting of very transverse meshes, very superficial on pronotum, distinct on elytra.

Eyes flattened, gena about a fourth as long as eye. Frontal foveae indistinct. Antennae moderately long, surpassing pronotal base by segments $10-11$. Mandibles moderately long. Apical two maxillary palpomeres equally long.

Pronotum convex, trapezoidal and large, more than twice as wide as head, barely narrower than elytra, broadest a fourth from base, evenly rounded on sides. Base very wide, wider than shared base of elytra, with median part mostly barely narrower than lateral lobes; the lobes large, projecting, barely oblique posterolaterad, more or less rounded posteriorly. Apex truncate to barely convex forward; apical angles rounded, barely projecting. Setigerous pore impressed, 4.4-5 pore diameters distant from lateral edge; apical bead entire. Lateral margin very widely explanate in basal half, not or indistinctly reflexed; lateral bead reaching basal angle. Median line fine, obliterate basally and apically. Transverse impressions indistinct or basal one hardly traceable. Basal foveae as very shallow oblong impressions just outside median part of base.

Elytra ovate due to wide bases, fairly short; extreme apices separated, narrowly rounded or blunt. Striae deep, very deep laterally; intervals $1-6$ slightly convex, more convex close to apex; 7 th and 8th distinctly narrower than others, costate basally, very convex behind. Interval 9 with 16 US; SSc adjoining stria 2. Parascutellar striole $1 / 2-2 / 3$ its length abbreviated anteriorly to obliterate.

Legs: $t a 2$ and $t a 3$ distinctly shorter than respective tibiae; $t i 2$ and $t i 3$ rather heavily armed, spiniform setae longer than width of respective tibiae. Metatarsomere 1 as long as metatarsomeres 2-4 combined; tarsomere 1 ( $t a 1$ ) or tarsomeres 12 (ta 2$)$, or tarsomeres 1-3 (ta 3$)$ rather shallowly bisulcate; pro- and mesotarsomere 4 with moderately long apical lobes. Protarsi barely dilated in male, with tarsomeres 1-2 biserially squamose on ventral side.

Male T9 with long subtriangular base (Fig. 22). Aedeagus median lobe with moderately wide bottom; apex triangular in lateral view, slightly curved ventrad; in ventral view nearly parallel-sided, with rounded tip (Figs 4142).

DIAGNOSIS. An Amara-like species of the group, with pale legs and pronotal setigerous pore being at a distance from lateral edge. Barely dilated protarsi, with ventral pad absent from tarsomere 3, is the next distinctive feature observed also in no congener but $D$. rotundatum sp.n.

DISTRIBUTION. Known from the type locality only.

NAME. Refers to the wide pronotum.

ACKNOWLEDGMENTS. I am much obliged to my Russian and Vietnamese colleagues from the Russia-Vietnam Tropical Center for their help during expeditions to Vietnam.

\section{References}

Fedorenko D.N. 2011. A new ground-beetle genus, Dalatagonum gen.n. (Coleoptera, Carabidae, Platynini), from Vietnam // Far Eastern Entomologist. Vol.233. P.1-23. 
Table. Measurements and ratios of the body in Dalatagonum.

Таблица. Промеры и пропорции тела Dalatagonum.

\begin{tabular}{l|c|c|c|c|c|c|c|c|c}
\hline \multicolumn{1}{c|}{ Species } & $\mathbf{n}$ & $\mathbf{H W} / \mathbf{P W}$ & mean & PW/PL & mean & EW/PW & mean & EL/EW & mean \\
\hline \multicolumn{1}{c}{ blattoides-group } & & $\mathbf{2 . 0 6}-\mathbf{2 . 3 3}$ & & $\mathbf{1 . 5 1}-\mathbf{1 . 6 3}$ & & $\mathbf{1 . 0}-\mathbf{1 . 1 3}$ & & $\mathbf{1 . 2 9}-\mathbf{1 . 4 3}$ \\
blattoides & 10 & $2.13-2.33$ & $\mathbf{2 . 2 5}$ & $1.53-1.60$ & $\mathbf{1 . 5 6}$ & $1.0-1.08$ & $\mathbf{1 . 0 3}$ & $1.33-1.43$ & $\mathbf{1 . 3 9}$ \\
ellipticum & 7 & $2.06-2.16$ & $\mathbf{2 . 1 1}$ & $1.51-1.60$ & $\mathbf{1 . 5 6}$ & $1.03-1.09$ & $\mathbf{1 . 0 6}$ & $1.29-1.33$ & $\mathbf{1 . 3 1}$ \\
sericeum & 1 & 2.23 & $\mathbf{2 . 2 3}$ & 1.63 & $\mathbf{1 . 6 3}$ & 1.02 & $\mathbf{1 . 0 2}$ & 1.39 & $\mathbf{1 . 3 9}$ \\
amariforme sp.n. & 5 & $2.16-2.28$ & $\mathbf{2 . 2 1}$ & $1.59-1.62$ & $\mathbf{1 . 6 0}$ & $1.08-1.13$ & $\mathbf{1 . 1 1}$ & $1.33-1.43$ & $\mathbf{1 . 3 8}$ \\
$\quad$ calathoides-group & & $\mathbf{1 . 6 8}-\mathbf{2 . 2 6}$ & & $\mathbf{1 . 0 3}-\mathbf{1 . 6 4}$ & & $\mathbf{1 . 0 8}-\mathbf{1 . 4 0}$ & & $\mathbf{1 . 3 3}-\mathbf{1 . 6 2}$ & \\
elongatum & 10 & $2.0-2.14$ & $\mathbf{2 . 0 6}$ & $1.25-1.35$ & $\mathbf{1 . 2 9}$ & $1.09-1.19$ & $\mathbf{1 . 1 3}$ & $1.49-1.62$ & $\mathbf{1 . 5 7}$ \\
calathoides & 10 & $1.90-2.02$ & $\mathbf{1 . 9 6}$ & $1.28-1.38$ & $\mathbf{1 . 3 2}$ & $1.18-1.30$ & $\mathbf{1 . 2 3}$ & $1.33-1.47$ & $\mathbf{1 . 3 9}$ \\
convexicolle sp.n. & 5 & $2.17-2.26$ & $\mathbf{2 . 2 1}$ & $1.59-1.64$ & $\mathbf{1 . 6 2}$ & $1.08-1.13$ & $\mathbf{1 . 1 2}$ & $1.36-1.43$ & $\mathbf{1 . 3 9}$ \\
broteroides & 1 & 1.68 & $\mathbf{1 . 6 8}$ & 1.03 & $\mathbf{1 . 0 3}$ & 1.40 & $\mathbf{1 . 4 0}$ & 1.51 & $\mathbf{1 . 5 1}$ \\
$\quad$ anickini-group & & $\mathbf{1 . 7 5}-\mathbf{2 . 0 1}$ & & $\mathbf{1 . 2 9}-\mathbf{1 . 4 5}$ & & $\mathbf{1 . 2 0}-\mathbf{1 . 4 0}$ & & $\mathbf{1 . 2 6}-\mathbf{1 . 3 2}$ & \\
anickini & 1 & 1.82 & $\mathbf{1 . 8 2}$ & 1.29 & $\mathbf{1 . 2 9}$ & 1.24 & $\mathbf{1 . 2 4}$ & 1.29 & $\mathbf{1 . 2 9}$ \\
rotundatum sp.n. & 5 & $1.93-2.01$ & $\mathbf{1 . 9 6}$ & $1.39-1.45$ & $\mathbf{1 . 4 2}$ & $1.20-1.26$ & $\mathbf{1 . 2 3}$ & $1.26-1.34$ & $\mathbf{1 . 3 0}$ \\
quadrisetosum sp.n. & 3 & $1.75-1.80$ & $\mathbf{1 . 7 7}$ & $1.39-1.44$ & $\mathbf{1 . 4 2}$ & $1.30-1.40$ & $\mathbf{1 . 3 6}$ & $1.30-1.32$ & $\mathbf{1 . 3 1}$ \\
$\quad$ bidoupense-group & & $\mathbf{1 . 9 2}-\mathbf{2 . 2 4}$ & & $\mathbf{1 . 3 8}-\mathbf{1 . 5 6}$ & & $\mathbf{1 . 0 4}-\mathbf{1 . 1 5}$ & & $\mathbf{1 . 2 9}-\mathbf{1 . 5 0}$ & \\
bidoupense & 9 & $1.92-2.03$ & $\mathbf{1 . 9 8}$ & $1.41-1.51$ & $\mathbf{1 . 4 5}$ & $1.08-1.15$ & $\mathbf{1 . 1 1}$ & $1.39-1.50$ & $\mathbf{1 . 4 4}$ \\
simile & 2 & $2.04-2.05$ & $\mathbf{2 . 0 5}$ & $1.38-1.42$ & $\mathbf{1 . 4 0}$ & $1.04-1.07$ & $\mathbf{1 . 0 6}$ & $1.40-1.49$ & $\mathbf{1 . 4 5}$ \\
rufipes sp.n. & 5 & $2.09-2.13$ & $\mathbf{2 . 1 1}$ & $1.51-1.56$ & $\mathbf{1 . 5 3}$ & $1.09-1.12$ & $\mathbf{1 . 1 0}$ & $1.29-1.34$ & $\mathbf{1 . 3 1}$ \\
laticolle sp.n. & 5 & $2.12-2.24$ & $\mathbf{2 . 1 6}$ & $1.50-1.54$ & $\mathbf{1 . 5 2}$ & $1.04-1.09$ & $\mathbf{1 . 0 7}$ & $1.27-1.30$ & $\mathbf{1 . 2 9}$ \\
\hline
\end{tabular}

EL — length of elytron, measured from the apicalmost point of the basal ridge to apex; EW — maximum width of elytra; HW — width of head across eyes; PL - length of pronotum along median line; PW — maximum width of pronotum; $\mathbf{n}$ - number of specimens measured.

Table (continued 1). Таблица (продолжение 1).

\begin{tabular}{|c|c|c|c|c|c|c|c|c|c|}
\hline Species & $\mathbf{n}$ & $\mathbf{P B} / \mathbf{P A}$ & mean & PLw/PL & mean & $\mathbf{P B m} / \mathbf{P B I}$ & mean & US & $\begin{array}{l}\text { BL, } \\
\text { mm }\end{array}$ \\
\hline blattoides-group & & $1.70-2.28$ & & $0.18-0.30$ & & $1.04-1.28$ & & & \\
\hline blattoides & 5 & $1.82-1.97$ & 1.90 & $0.20-0.24$ & 0.21 & $1.08-1.25$ & 1.19 & 16 & $6.4-7.7$ \\
\hline ellipticum & 5 & $1.70-1.84$ & 1.79 & $0.19-0.22$ & 0.21 & $1.14-1.20$ & 1.17 & 15 & $4.3-4.9$ \\
\hline sericeum & 1 & 2.28 & 2.28 & 0.20 & 0.20 & 1.28 & 1.28 & 16 & 5.6 \\
\hline amariforme sp.n. & 5 & $1.81-2.0$ & 1.94 & $0.18-0.30$ & 0.25 & $1.04-1.20$ & 1.08 & 16 & $5.9-6.5$ \\
\hline calathoides-group & & $1.18-1.84$ & & $0.26-0.55$ & & $1.46-3.68$ & & & \\
\hline elongatum & 5 & $1.48-1.59$ & 1.54 & $0.30-0.41$ & 0.35 & $1.48-1.75$ & 1.63 & 16 & $9-10$ \\
\hline calathoides & 5 & $1.56-1.64$ & 1.61 & $0.33-0.37$ & 0.35 & $1.90-2.20$ & 2.06 & 16 & $6.7-8.1$ \\
\hline convexicolle sp.n. & 5 & $1.70-1.84$ & 1.77 & $0.26-0.37$ & 0.32 & $1.46-1.62$ & 1.53 & 16 & $6.9-8.3$ \\
\hline broteroides & 1 & 1.18 & 1.18 & 0.55 & 0.55 & 3.68 & 3.68 & 16 & 8.6 \\
\hline anickini-group & & $1.30-1.48$ & & $0.46-0.59$ & & $1.26-1.63$ & & & \\
\hline anickini & 1 & 1.45 & 1.45 & 0.46 & 0.46 & 1.26 & 1.26 & 16 & 5.6 \\
\hline rotundatum sp.n. & 5 & $1.39-1.48$ & 1.43 & $0.46-0.49$ & 0.47 & $1.30-1.44$ & 1.34 & $14-16$ & $5.4-6.3$ \\
\hline quadrisetosum sp.n. & 3 & $1.30-1.40$ & 1.37 & $0.58-0.59$ & 0.58 & $1.50-1.63$ & 1.54 & 15 & $5.8-5.9$ \\
\hline bidoupense-group & & $1.50-1.98$ & & $0.17-0.41$ & & $0.85-1.33$ & & & \\
\hline bidoupense & 5 & $1.50-1.63$ & 1.59 & $0.35-0.42$ & 0.38 & $1.0-1.33$ & 1.16 & 15 & $4.9-5.6$ \\
\hline simile & 2 & $1.63-1.70$ & 1.67 & $0.35-0.41$ & 0.38 & $1.04-1.09$ & 1.07 & 15 & 5.6 \\
\hline rufipes sp.n. & 5 & $1.88-1.98$ & 1.91 & $0.17-0.29$ & 0.23 & $0.92-1.09$ & 1.01 & 15 & $5-5.4$ \\
\hline laticolle sp.n. & 5 & $1.69-1.98$ & 1.87 & $0.20-0.32$ & 0.24 & $0.85-1.0$ & 0.92 & 16 & $5.3-6.1$ \\
\hline
\end{tabular}

BL - maximum body length, measured between apices of closed mandibles and apices of elytra; PA — width of pronotum between apical angles; PB — width of pronotal base; PBl — width of lateral lobes of pronotal base; PBm — width of median part of pronotal base; PL — length of pronotum along median line; PLw — distance between base and level of maximum width of pronotum; PW — maximum width of pronotum; US - number of umbilical setae in elytral interval $9 ; \mathbf{n}$ - number of specimens measured. 
Table (continued 2). Таблица (продолжение 2).

\begin{tabular}{|c|c|c|c|c|c|c|c|c|c|c|c|}
\hline \multirow[b]{2}{*}{ Species } & \multirow[b]{2}{*}{$\mathbf{n}$} & \multicolumn{6}{|c|}{ Antennal ratio (AR) } & \multirow[b]{2}{*}{$\mathbf{n}$} & \multicolumn{3}{|c|}{ SSc ratio } \\
\hline & & A1L/A3L & mean & A2L/A3L & mean & A4L/A3L & mean & & $\mathbf{s} / \mathbf{n}$ & $\begin{array}{c}\mathbf{s - a} \\
(\mathbf{a}-\mathbf{s}) / \\
\mathbf{n}\end{array}$ & $\mathbf{a} / \mathbf{n}$ \\
\hline blattoides-group & & $1.05-1.49$ & & $0.54-0.76$ & & $1.15-1.48$ & & & & & \\
\hline blattoides & 5 & $1.15-1.25$ & 1.19 & $0.54-0.58$ & 0.57 & $1.15-1.33$ & 1.23 & 20 & 0.25 & 0.35 & 0.40 \\
\hline ellipticum & 5 & $1.23-1.49$ & 1.36 & $0.65-0.76$ & 0.73 & $1.24-1.28$ & 1.27 & 16 & - & 0.14 & 0.86 \\
\hline sericeum & 1 & 1.21 & 1.21 & 0.71 & 0.71 & 1.31 & 1.31 & 1 & - & 1 & - \\
\hline amariforme sp.n. & 5 & $1.05-1.21$ & 1.11 & $0.57-0.60$ & 0.58 & $1.30-1.48$ & 1.38 & 13 & 0.08 & 0.08 & 0.85 \\
\hline calathoides-group & & $0.80-1.04$ & & $0.44-0.57$ & & $1.06-1.36$ & & & & & \\
\hline elongatum & 5 & $0.84-0.92$ & 0.88 & $0.46-0.49$ & 0.48 & $1.08-1.17$ & 1.13 & 25 & 0.40 & 0.12 & 0.48 \\
\hline calathoides & 5 & $0.94-1.04$ & 0.99 & $0.52-0.57$ & 0.54 & $1.14-1.36$ & 1.27 & 14 & 0.36 & 0.14 & 0.50 \\
\hline convexicolle sp.n. & 5 & $0.88-0.93$ & 0.90 & $0.50-0.54$ & 0.52 & $1.18-1.22$ & 1.20 & 15 & 0.53 & 0.20 & 0.27 \\
\hline broteroides & 1 & 0.80 & 0.80 & 0.44 & 0.44 & 1.06 & 1.06 & 1 & - & 1 & - \\
\hline anickini-group & & 0.94-1.09 & & $0.53-0.64$ & & $1.18-1.27$ & & & & & \\
\hline anickini & 1 & 1.05 & 1.05 & 0.53 & 0.53 & 1.18 & 1.18 & 1 & - & 1 & - \\
\hline rotundatum sp.n. & 5 & $0.94-1.02$ & 0.97 & $0.53-0.57$ & 0.55 & $1.18-1.27$ & 1.24 & 7 & 1 & - & - \\
\hline quadrisetosum sp.n. & 3 & $1.05-1.09$ & 1.08 & $0.58-0.64$ & 0.61 & $1.18-1.27$ & 1.22 & 3 & - & - & 1 \\
\hline bidoupense-group & & $1.01-1.28$ & & $0.57-0.69$ & & $1.13-1.29$ & & & & & \\
\hline bidoupense & 5 & $1.14-1.21$ & 1.18 & $0.60-0.67$ & 0.65 & $1.24-1.28$ & 1.27 & 8 & 0.38 & 0.35 & 0.38 \\
\hline simile & 1 & 1.28 & 1.28 & 0.69 & 0.69 & 1.28 & 1.28 & 2 & 0.5 & 0.5 & - \\
\hline rufipes sp.n. & 5 & $1.08-1.19$ & 1.12 & $0.61-0.66$ & 0.63 & $1.13-1.27$ & 1.21 & 6 & 1 & - & - \\
\hline laticolle sp.n. & 5 & $1.01-1.12$ & 1.08 & $0.57-0.64$ & 0.60 & $1.23-1.29$ & 1.26 & 7 & 0.14 & - & 0.86 \\
\hline
\end{tabular}

AmL - lengths of antennomeres 1 to $4(\mathrm{~m}=1,2,3,4)$; SSc - parascutellar seta ratio $(s+s-a[a-s]+a=1, a-$ number of specimens with parascutellar seta $[S S c]$ adjoining either stria 2 or short common base of striae 1 and $2, s$ - number of specimens with $S S c$ separated from stria 2); $\mathbf{n}$ - number of specimens measured.

Table (continued 3). Таблица (продолжение 3).

\begin{tabular}{|c|c|c|c|c|c|c|c|c|}
\hline Species & $\mathbf{n}$ & $\begin{array}{l}\text { ES3L/ } \\
\text { ES3W }\end{array}$ & mean & n & $\begin{array}{l}\text { MT1L/ } \\
\text { MT2-4L }\end{array}$ & mean & $\mathbf{n}$ & $\begin{array}{l}\text { MXP4L/ } \\
\text { MXP3L }\end{array}$ \\
\hline blattoides-group & & $1.29-2.0$ & & & $1.0-1.21$ & & & $1.0-1.42$ \\
\hline blattoides & 5 & $1.50-2.0$ & 1.70 & 5 & $1.0-1.10$ & 1.05 & 2 & $1.05-1.07$ \\
\hline ellipticum & 3 & $1.29-1.57$ & 1.45 & 5 & $1.06-1.13$ & 1.10 & 2 & $1.25-1.42$ \\
\hline sericeum & 1 & 1.29 & 1.29 & 1 & 1.21 & 1.21 & 2 & 1.21 \\
\hline amariforme sp.n. & 5 & $1.57-1.65$ & 1.61 & 5 & $1.07-1.18$ & 1.12 & 2 & $1.0-1.03$ \\
\hline calathoides-group & & $1.17-1.69$ & & & $0.80-1.0$ & & & $0.77-0.92$ \\
\hline elongatum & 5 & $1.29-1.56$ & 1.41 & 5 & $0.89-0.95$ & 0.91 & 2 & $0.77-0.79$ \\
\hline calathoides & 5 & $1.54-1.69$ & 1.61 & 5 & $0.80-1.0$ & 0.94 & 2 & $0.88-0.91$ \\
\hline convexicolle sp.n. & 5 & $1.20-1.37$ & 1.30 & 5 & $0.87-1.0$ & 0.95 & 2 & $0.85-0.92$ \\
\hline broteroides & 1 & 1.17 & 1.17 & 1 & 0.83 & 0.83 & 1 & 0.81 \\
\hline anickini-group & & $1.20-1.73$ & & & $0.81-1.11$ & & & $1.17-1.47$ \\
\hline anickini & 1 & 1.73 & 1.73 & 1 & 0.81 & 0.81 & 1 & 1.17 \\
\hline rotundatum sp.n. & 3 & $1.20-1.54$ & 1.40 & 5 & $0.90-1.11$ & 0.98 & 2 & $1.17-1.21$ \\
\hline quadrisetosum sp.n. & 1 & 1.67 & 1.67 & 3 & $0.86-0.92$ & 0.88 & 2 & $1.39-1.47$ \\
\hline bidoupense-group & & $1.25-1.60$ & & & 0.96-1.29 & & & $1.0-1.44$ \\
\hline bidoupense & 3 & $1.50-1.60$ & 1.55 & 5 & $1.08-1.14$ & 1.10 & 2 & $1.09-1.15$ \\
\hline simile & 2 & 1.55 & 1.55 & 2 & $0.96-1.05$ & 1.01 & 2 & $1.18-1.22$ \\
\hline rufipes sp.n. & 2 & $1.42-1.43$ & 1.43 & 5 & $1.17-1.29$ & 1.23 & 2 & $1.28-1.44$ \\
\hline laticolle sp.n. & 5 & $1.25-1.54$ & 1.45 & 5 & $1.0-1.05$ & 1.02 & 2 & 1.0 \\
\hline
\end{tabular}

Es3L — length of metepisternum along basal margin; Es3W — width of metepisternum along outer margin; MT1L — length of metatarsomere 1; MT2-4L — length of metatarsomeres 2 to 4 combined, excluding apical lobes of MT4; MxP3L — length of maxillary palpomere 3; MxP4L - length of maxillary palpomere 4; $\mathbf{n}$ - number of specimens measured. 